Prepared in cooperation with Bowie Mining Company

\title{
Evaluation of Streamflow Gain-Loss Characteristics of Hubbard Creek, in the Vicinity of a Mine-Permit Area, Delta County, Colorado, 2007
}

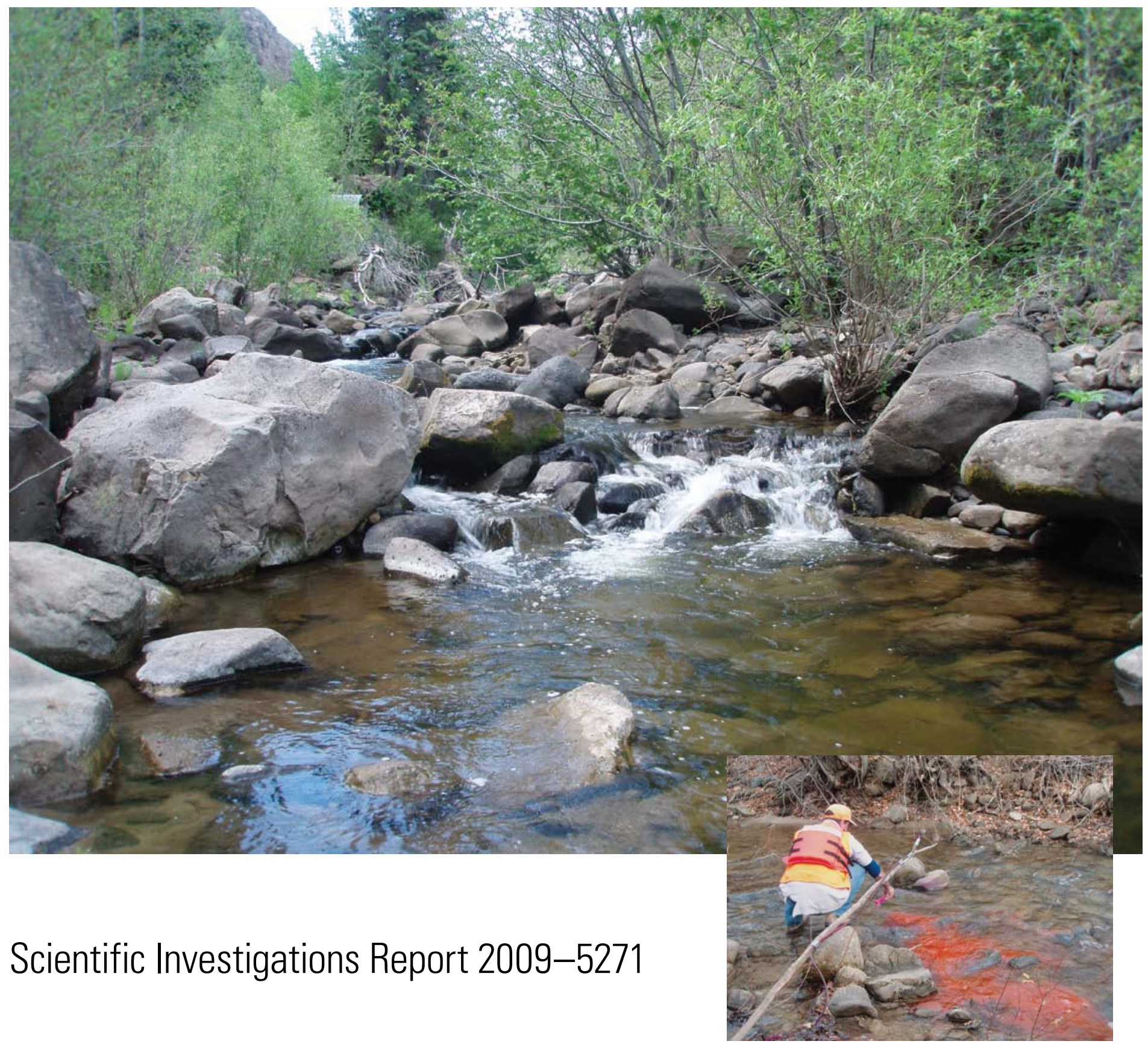

U.S. Department of the Interior U.S. Geological Survey 
On cover: Large photograph: Hubbard Creek at site 1.

Small photograph: U.S. Geological Survey hydrologist injecting tracers.

Photographs by Cory A. Williams, U.S. Geological Survey. 


\section{Evaluation of Streamflow Gain-Loss Characteristics of Hubbard Creek, in the Vicinity of a Mine-Permit Area, Delta County, Colorado, 2007}

By Barbara C. Ruddy and Cory A. Williams

Prepared in cooperation with Bowie Mining Company

Scientific Investigations Report 2009-5271 


\title{
U.S. Department of the Interior \\ KEN SALAZAR, Secretary \\ U.S. Geological Survey \\ Marcia K. McNutt, Director
}

\section{U.S. Geological Survey, Reston, Virginia: 2010}

\author{
For more information on the USGS — the Federal source for science about the Earth, its natural and living resources, \\ natural hazards, and the environment, visit http://www.usgs.gov or call 1-888-ASK-USGS \\ For an overview of USGS information products, including maps, imagery, and publications, \\ visit http://www.usgs.gov/pubprod \\ To order this and other USGS information products, visit http://store.usgs.gov
}

\begin{abstract}
Any use of trade, product, or firm names is for descriptive purposes only and does not imply endorsement by the U.S. Government.

Although this report is in the public domain, permission must be secured from the individual copyright owners to reproduce any copyrighted materials contained within this report.
\end{abstract}

Suggested citation:

Ruddy, B.C., and Williams, C.A., 2010, Evaluation of streamflow gain-loss characteristics of Hubbard Creek, in the vicinity of a mine-permit area, Delta County, Colorado, 2007: U.S. Geological Survey Series Scientific Investigations Report 2009-5271, 20 p. 


\section{Contents}

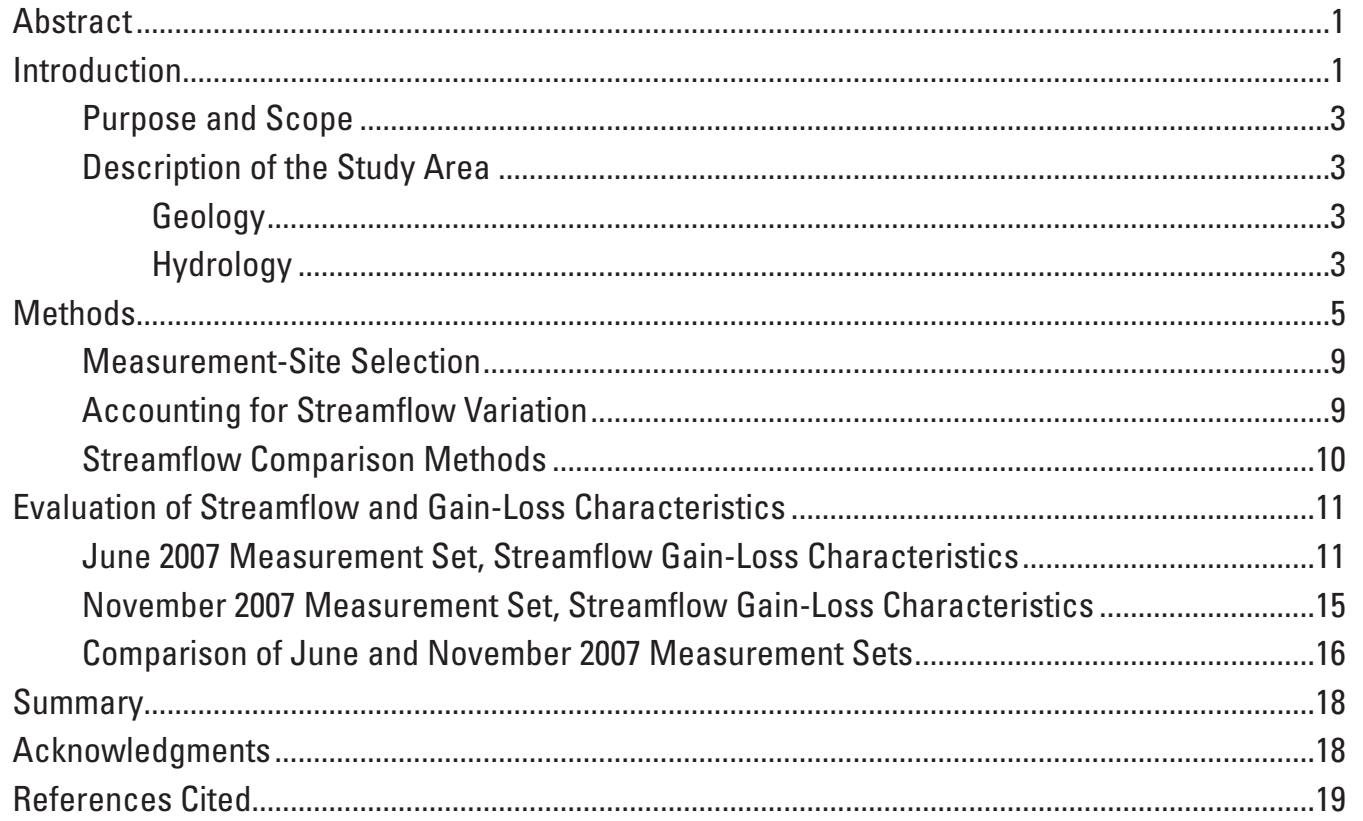

\section{Figures}

1. Map showing location of Hubbard Creek study area, measurement sites, and mine-permit area...................................................................................................

2. Map showing generalized geology of Hubbard Creek study area ....................................4

3-5. Graphs showing:

3. Streamflow data for stations 09132940, Hubbard Creek above Iron Point Gulch near Bowie, C0, and 09132960, Hubbard Creek at Highway 133 at mouth near Bowie, CO, June 1-0ctober 31, 2006.

4. Streamflow data for stations 09132940, Hubbard Creek above Iron Point Gulch near Bowie, C0, and 09132960, Hubbard Creek at Highway 133 at mouth near Bowie, CO, June 1-November 15, 2007 .7

5. Streamflow data for station 09132960, Hubbard Creek at Highway 133 at mouth near Bowie, C0, October 2002 through November 2007 .8

6. Schematic of tracer-design setup at a measurement site on Hubbard Creek .9

7-11. Graphs showing:

7. Estimated streamflows at site 2 for rhodamine WT and sodium bromide tracers, June 28, 2007

8. Streamflow data for stations 09132940, Hubbard Creek above Iron Point Gulch near Bowie, CO, and 09132960, Hubbard Creek at Highway 133 at mouth near Bowie, $\mathrm{CO}$, and streamflow estimated from discrete tracer samples, June 26-27, 2007, at about 11:50 a.m.

9. Estimated streamflows at sites 2-4, June 26-27, 2007 ...........................................16 
10. Streamflow data for station 09132960, Hubbard Creek at Highway 133 at mouth near Bowie, $\mathrm{CO}$, and streamflow estimated from discrete and continuously recorded tracer samples, November 8-9, 2007.

11. Estimated streamflows at sites 2 and 4, November 8-9, 2007

\section{Tables}

1. Streamflow measurement sites and streamflow-gaging stations .8

2. Traveltime estimates collected June 25 and November 7, 2007 ....................................10

3. Results for tracer-comparison study, Hubbard Creek, June 28, 2007 ..............................11

4. Results for modified multiple-tracer method, Hubbard Creek, June and November 2007

5. Various statistics for the measurement pairs by site, June and November, 2007 


\section{Conversion Factors and Datums}

\begin{tabular}{lll}
\hline \multicolumn{1}{c}{ Multiply } & By & \multicolumn{1}{c}{ To obtain } \\
\hline \multicolumn{3}{c}{ Length } \\
\hline inch (in.) & 2.54 & centimeter $(\mathrm{cm})$ \\
foot $(\mathrm{ft})$ & 0.3048 & meter $(\mathrm{m})$ \\
mile $(\mathrm{mi})$ & 1.609 & kilometer $(\mathrm{km})$ \\
\hline \multicolumn{3}{c}{ Area } \\
\hline square mile $\left(\mathrm{mi}^{2}\right)$ & 2.590 & square kilometer $\left(\mathrm{km}^{2}\right)$ \\
\hline \multicolumn{3}{c}{ Volume } \\
\hline gallon (gal) & 3.785 & liter $(\mathrm{L})$ \\
gallon $($ gal) & 0.003785 & cubic meter $\left(\mathrm{m}^{3}\right)$ \\
\hline & Flow rate \\
cubic foot per second $\left(\mathrm{ft}^{3} / \mathrm{s}\right)$ & 0.02832 & cubic meter per second $\left(\mathrm{m}^{3} / \mathrm{s}\right)$ \\
\hline
\end{tabular}

Temperature in degrees Celsius $\left({ }^{\circ} \mathrm{C}\right)$ may be converted to degrees Fahrenheit $\left({ }^{\circ} \mathrm{F}\right)$ as follows:

$$
{ }^{\circ} \mathrm{F}=\left(1.8 x^{\circ} \mathrm{C}\right)+32
$$

Temperature in degrees Fahrenheit $\left({ }^{\circ} \mathrm{F}\right)$ may be converted to degrees Celsius $\left({ }^{\circ} \mathrm{C}\right)$ as follows:

$$
{ }^{\circ} \mathrm{C}=\left({ }^{\circ} \mathrm{F}-32\right) / 1.8
$$

Vertical coordinate information is referenced to the North American Vertical Datum of 1988 (NAVD 88).

Horizontal coordinate information is referenced to the North American Datum of 1983 (NAD 83).

Elevation, as used in this report, refers to distance above the vertical datum.

Specific conductance is given in microsiemens per centimeter at 25 degrees Celsius $(\mu \mathrm{S} / \mathrm{cm}$ at $\left.25^{\circ} \mathrm{C}\right)$.

Concentrations of chemical constituents in water are given either in milligrams per liter (mg/L) or micrograms per liter $(\mu \mathrm{g} / \mathrm{L})$. 


\section{Abbreviations}

L/min liters per minute

$\mathrm{mL} \quad$ milliliters

BLM Bureau of Land Management

$\mathrm{NaBr}$ sodium bromide

Rh WT rhodamine WT

USGS U.S. Geological Survey

NWOL U.S. Geological Survey National Water-Quality Laboratory

WY Water year-A continuous 12-month period representing an annual hydrologic cycle selected to present data relative to hydrologic or meteorological phenomena. The water year used by the U.S. Geological Survey runs from October 1 through September 30 and is designated by the year in which it ends. 


\title{
Evaluation of Streamflow Gain-Loss Characteristics of Hubbard Creek, in the vicinity of a Mine-Permit Area, Delta County, Colorado, 2007
}

\author{
By Barbara C. Ruddy and Cory A. Williams
}

\section{Abstract}

In 2007, the U.S. Geological Survey, in cooperation with Bowie Mining Company, initiated a study to characterize the streamflow and streamflow gain-loss in a reach of Hubbard Creek in Delta County, Colorado, in the vicinity of a minepermit area planned for future coal mining. Premining streamflow characteristics and streamflow gain-loss variation were determined so that pre- and postmining gain-loss characteristics could be compared. This report describes the methods used in this study and the results of two streamflow-measurement sets collected during low-flow conditions.

Streamflow gain-loss measurements were collected using rhodamine WT and sodium bromide tracers at four sites spanning the mine-permit area on June 26-28, 2007. Streamflows were estimated and compared between four measurement sites within three stream subreaches of the study reach. Data from two streamflow-gaging stations on Hubbard Creek upstream and downstream from the mine-permit area were evaluated. Streamflows at the stations were continuous, and flow at the upstream station nearly always exceeded the streamflow at the downstream station. Furthermore, streamflow at both stations showed similar diurnal patterns with traveltime offsets.

On June 26, streamflow from the gain-loss measurements was greater at site 1 (most upstream site) than at site 4 (most downstream site); on June 27, streamflow was greater at site 4 than at site 2; and on June 27, there was no difference in streamflow between sites 2 and 3. Data from streamflowgaging stations 09132940 and 09132960 showed diurnal variations and overall decreasing streamflow over time. The data indicate a dynamic system, and streamflow can increase or decrease depending on hydrologic conditions. The streamflow within the study reach was greater than the streamflows at either the upstream or downstream stations.

A second set of gain-loss measurements was collected at sites 2 and 4 on November 8-9, 2007. On November 8, streamflow was greater at site 4 than at site 2 , and on the following day, November 9, streamflow was greater at site 2 than at site 4. Data collection on November 8 occurred while the streamflow was increasing due to contributions from stream ice melting throughout different parts of the basin. Data collection on November 9 occurred earlier in the day with less stream ice melting and more steady-state conditions, so the indication that streamflow decreased between sites 2 and 4 may be more accurate.

Diurnal variations in streamflow are common at both the upper and the lower streamflow-gaging stations. The upper streamflow-gaging station shows a melt-freeze influence from tributaries to Hubbard Creek during the winter season. Downstream from the study reach, observed diurnal variation is likely due to evapotranspiration associated with dense floodplain vegetation, which consumes water from the creek during the middle of the day. Varying diurnal patterns in streamflow, combined with possible variations in tributary inflows to Hubbard Creek in the study reach, probably account for the observed variations in streamflow at the tracer measurement sites.

During both sampling periods in June and November 2007, conditions were less than ideal and not steady state. The June 27 sampling indicates that the streamflow was increasing between measurement sites 2 and 4, and the November 9 sampling indicates that the streamflow was decreasing between measurement sites 2 and 4 . The data collected during the diurnal and day-to-day variations in streamflow indicated that the streamflow reach is dynamic and can be gaining, losing, or constant.

\section{Introduction}

Hubbard Creek is in western Colorado along the North Fork of the Gunnison River, northeast of Paonia (fig. 1). The watershed overlies sedimentary rock formations of Cretaceous age that are rich in economical coal deposits. Underground coal mining has occurred in the North Fork Gunnison area since about 1900. The Bowie Mine has been active between Terror and Hubbard Creeks since about 1952 (fig. 1) (Chaney and others, 1987; Williams and Leib, 2005). Mining operators anticipate increased mining activity in the western part of the permit area initially under Terror Creek and later under Hubbard Creek. 


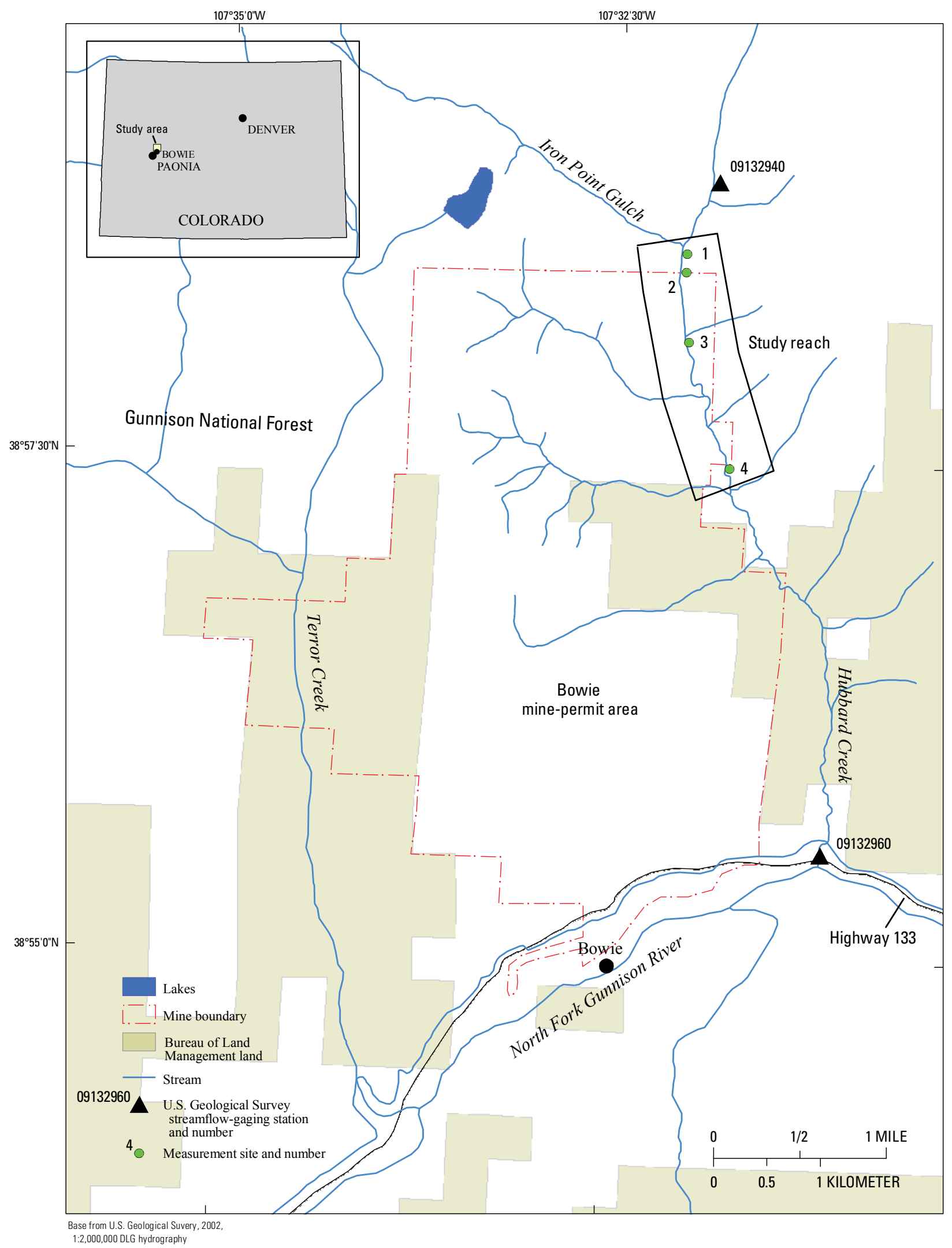

Figure 1. Location of Hubbard Creek study area, measurement sites, and mine-permit area. 
The coal is extracted using a continuous mining technique. In the primary step, referred to as "first mining," the coal is extracted in a crosshatched pattern that leaves regularly spaced pillars of coal to support the roof of the mine. Later these support columns are removed to increase the amount of mined coal. This removal of the support columns can cause fracturing and subsidence in the overlying formations (Dunrud, 1976). The magnitude and extent of this fracturing from mining activities in the Bowie Mine is unknown, but if it extends close to the ground surface, streamflow in Hubbard Creek could be affected. If groundwater contributes to surfacewater flow prior to the mining, groundwater in a postmining period could instead be diverted away from the stream as a result of possible fracturing and subsidence. Information is needed prior to mining in the vicinity of Hubbard Creek to determine baseline streamflow and gain-loss characteristics of Hubbard Creek that may be used to determine if future changes may occur in streamflow due to mining activities. In order to address this issue, the U.S. Geological Survey (USGS), in cooperation with the Bowie Mining Company, began a study to characterize streamflow and gain-loss characteristics of Hubbard Creek.

\section{Purpose and Scope}

The purpose of this report is to describe the datacollection methods and streamflow gain-loss characteristics of Hubbard Creek in the vicinity of the Bowie mine-permit area. Data were collected at four sites during low streamflows in June 2007 and at two sites in November 2007. The report also contains a discussion of streamflow analysis and data at the two USGS streamflow-gaging stations located upstream and downstream from the study area.

\section{Description of the Study Area}

Hubbard Creek is in western Colorado about $1.3 \mathrm{mi}$ northeast of Bowie, Colorado (fig. 1). The headwaters (elevation almost 10,400 ft) originate in the Gunnison National Forest on the southeastern flank of the Grand Mesa (about 14 mi northwest of Bowie, Colo.). The creek initially flows east to northeast to Hubbard Park (about 9 mi north-northwest of Bowie, Colo.) at an elevation of about $8,800 \mathrm{ft}$, where it flows southeast and then south to its confluence with the North Fork Gunnison River at an elevation of about 5,880 ft. The Hubbard Creek stream study reach extends about $1.4 \mathrm{mi}$ along the northeast boundary of the mine-permit area.

Throughout the study area, the Hubbard Creek stream channel consists mostly of areas braided by cobbles and boulders surrounded by gravels and sands. Some large, 13- to 14-ft-diameter boulders are present, but they are rare. The stream gradient is mostly flat, but there are some riffles and cascades in areas of steeper gradients. Generally, the streamflow is smooth and basically laminar. Farther downstream within the study reach, the gradient generally is less steep and the boulders and cobbles are smaller. The streambed material typically is alluvium with some colluvium. No exposed bedrock channel was observed near the sampling sites. There is little or no vegetation on the stream bottom in the active channel, but there are occasional stream bars with vegetation in the stream channel.

The valley bottom cross section is typically steep, almost V-shaped, but with some flatter flood-plain areas. There are few exposed rock outcrops, and much of the terrain is covered by oak brush, deciduous forest, and some evergreens. The stream channel is generally 15 to $25 \mathrm{ft}$ wide. Thick vegetation grows along the stream channel, making stream access difficult. The tree canopy is dense and overhangs the stream channel by 5 to $10 \mathrm{ft}$.

Annual precipitation ranges from 17 to 35 inches, most of which occurs as snow at higher elevations during late winter and early spring (DiLuzio, 2007). Primary land use is coal mining. Underground coal-mining production from the Bowie \#2 Mine was ranked 36th in coal production in the United States in 2007, with nearly 5.4 million short tons produced annually by one local mining company (Energy Information Administration, 2008). Some agricultural use occurs downstream from the study area. Most of the basin is managed by the U.S. Department of Agriculture Forest Service and U.S. Department of the Interior Bureau of Land Management (BLM) with some isolated private land holdings (Theobald and others, 2008).

\section{Geology}

The predominant geologic outcrop within the study reach is the Upper Cretaceous Mesaverde Formation (fig. 2) (Green, 1992), which consists of interbedded sandstones, siltstones, and shales. The Cretaceous Mancos Shale is present downstream from the study reach, in the southern part of the minepermit area. Geologic formations near the town of Paonia generally dip 5 degrees north into the Grand Mesa (Brooks, 1983; Ellis and others, 1987; and Dunrud, 1976). Some of the faulting and fracturing in the area may be related to mining.

The study reach contains economic deposits of bituminous coal bounded by layers of shale and sandstone within the Mesaverde Formation. The deposits are present intermittently as much as $600 \mathrm{ft}$ above the Rollins Sandstone Member, a 150-ft-thick basal sandstone unit of the Mesaverde Formation (Brooks, 1983). The most likely coalbed to be mined is the D-seam. It has high-Btu content $(12,000+)$ with a very low (0.5 percent) sulfur content (Oxbow Corporation, 2008; Bowie Resources, Limited, 2008).

\section{Hydrology}

Hubbard Creek is a perennial stream that flows into the North Fork Gunnison River just east of Bowie, Colorado. There are two USGS streamflow-gaging stations along Hubbard Creek that have been in operation since 2001 (fig.1). 


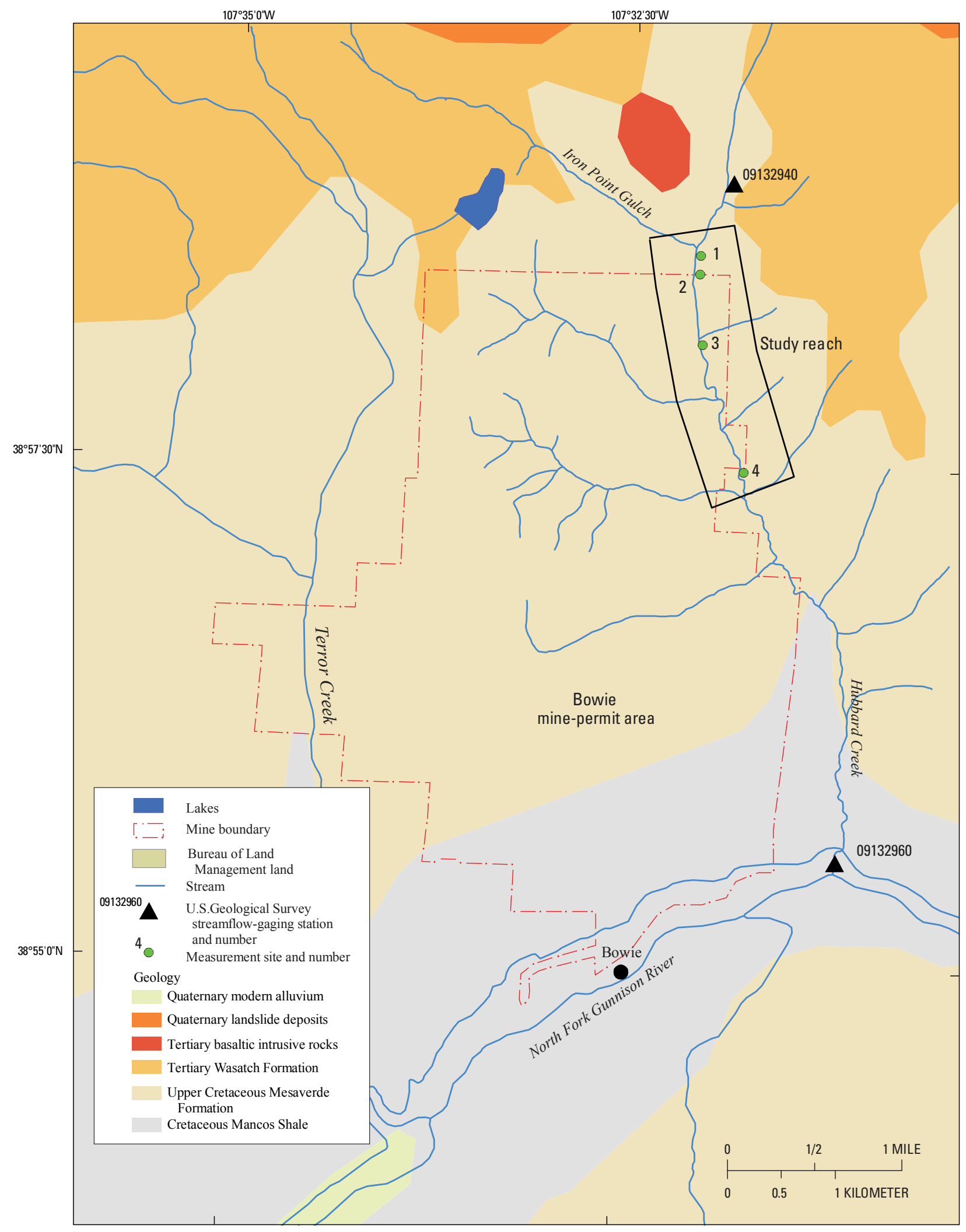

Figure 2. Generalized geology of Hubbard Creek study area (Green, 1992). 
Station 09132940, Hubbard Creek above Iron Point Gulch near Bowie, Colorado, is about $0.5 \mathrm{mi}$ upstream from the mine-permit area. It operates seasonally from June though October, except for 2001 when it was operated from August through October. Station 09132960, Hubbard Creek at Highway 133 at mouth near Bowie, Colorado, is more than $2.0 \mathrm{mi}$ downstream from the mine-permit area and it is operated year round. There are no known diversions between the upstream station and the mine-permit area or within the mine-permit area. There are multiple diversions upstream from the upstream station and downstream from the mine-permit area. Streamflow at the downstream station is affected by two irrigation diversions. During the irrigation season (mid-April through mid-October depending on need), all of the streamflow in Hubbard Creek downstream from the study area and upstream from station 09132960 can be diverted (Stephen Tuck, Colorado Department of Natural Resources, written commun., January 2010).

Streamflows at the two stations were continuous and followed the same patterns with an offset for traveltime between the two stations. Streamflow at the upstream station generally exceeded the streamflow at the downstream station. Hydrographs for June 1 through October 31, 2006 (fig. 3), and June 1 through November 15, 2007 (fig. 4), show that streamflow at the downstream station was consistently less than at the upstream station except for October 2006 when the streamflows were almost the same. This general difference in streamflow also occurred during 2002 through 2005 (U.S. Geological Survey, 2008). This pattern may be due to diversions downstream from the mine-permit area, evapotranspiration, and gradual streamflow loss to groundwater between the streamflow-gaging stations, or it may be due to streamflow loss to the alluvium as Hubbard Creek flows into the valley bottom of the North Fork Gunnison and agricultural land.

Most Hubbard Creek streamflow is derived from snowmelt runoff. The highest streamflows at the downstream station at the mouth occur during early spring, mid-April to early May (fig. 5). Streamflow peaked at around $125 \mathrm{ft}^{3} / \mathrm{s}$ during 2007, but the peak has ranged from $55 \mathrm{ft}^{3} / \mathrm{s}$ to $380 \mathrm{ft}^{3} / \mathrm{s}$ since 2002. Streamflow generally stays below $10 \mathrm{ft}^{3} / \mathrm{s}$ when water is diverted from the creek for irrigation. A smaller peak occurs each fall when irrigation is discontinued. Tributaries within the study area that contribute flow to Hubbard Creek during snowmelt and late summer monsoon rainfall were not flowing during the study (June and November 2007).

\section{Methods}

Tracer methods were used to determine streamflow at four measurement sites (table 1) because reconnaissance of the study area in June 2005 and in June 2007 showed largesized bed materials (such as boulders) in combination with steep gradients (greater than 0.01 slopes), which precluded the use of traditional current meters and standard streamflowmeasurement techniques (Rantz and others, 1982). Under these conditions traditional current-meter measurements tend to underestimate the true velocity and streamflow (Marchand and others, 1984) in part because of the difficulty in making accurate depth measurements and the inability of traditional methods to measure the turbulent and multiangular flow. Therefore, streamflow was measured in Hubbard Creek by using chemical tracers. This method uses the principle of conservation of mass to calculate streamflow (Rantz and others, 1982; Kilpatrick and Cobb, 1985). The initial reconnaissance of Hubbard Creek and the results of the Terror Creek gain-loss investigation indicated that Hubbard Creek may contain stream segments that are losing streamflow (Williams and Leib, 2005). Traditional streamflow measurements by tracer-injection methods cannot indicate streamflow loss because the tracer loss is proportional to the streamflow loss, the stream-water concentration is not affected, and loss cannot be detected from a change in tracer concentration (Zellweger, 1994). Therefore, a modified method of streamflow determination was used that accounts for streamflow loss with the use of multiple-injection sites. Separate constant-rate injections at four measurement sites were coordinated along the Hubbard Creek study reach. The method is described by Williams and Leib (2005). One refinement was made in the Hubbard Creek study: instead of one tracer type being used at the upstream and downstream measurement pairs, two different tracers were used. At the upstream measurement sites in June (sites 1-3) and the downstream site in November (site 4), a solution of rhodamine WT and stream water was used. At the downstream measurement sites in June (sites 3-4) and the upstream site in November (site 2), a solution of sodium bromide $(\mathrm{NaBr})$ and stream water was used as the tracer. By using two different tracer types, interference between tracers between the upstream and downstream measurement sites would be minimal and the conservation of mass of the two tracers could be verified.

Streamflow was computed, using the equation developed by Rantz and others (1982) for calculating streamflows using tracers. The equation follows:

where

$$
Q=\left[\left(C_{1}-C_{2}\right) Q_{1}\right] /\left[\left(C_{2}-C_{b}\right) K\right]
$$

$Q \quad$ is the streamflow of the stream, in cubic feet per second;

$C_{1}$ is the concentration (either rhodamine WT or $\mathrm{NaBr}$ ) of the tracer solution injectate, in milligrams per liter;

$C_{2}$ is the downstream concentration of either rhodamine WT or $\mathrm{NaBr}$ completely mixed with the stream, in milligrams per liter;

$Q_{1}$ is the rate of flow of the injected tracer solution, in milligrams per liter;

$C_{b}$ is the background tracer concentration (either rhodamine WT or $\mathrm{NaBr}$ ) of the stream, in milligrams per liter; and

$K$ is a metric-to-standard units conversion factor $\left(1.6992 \times 10^{3}\right)$. 


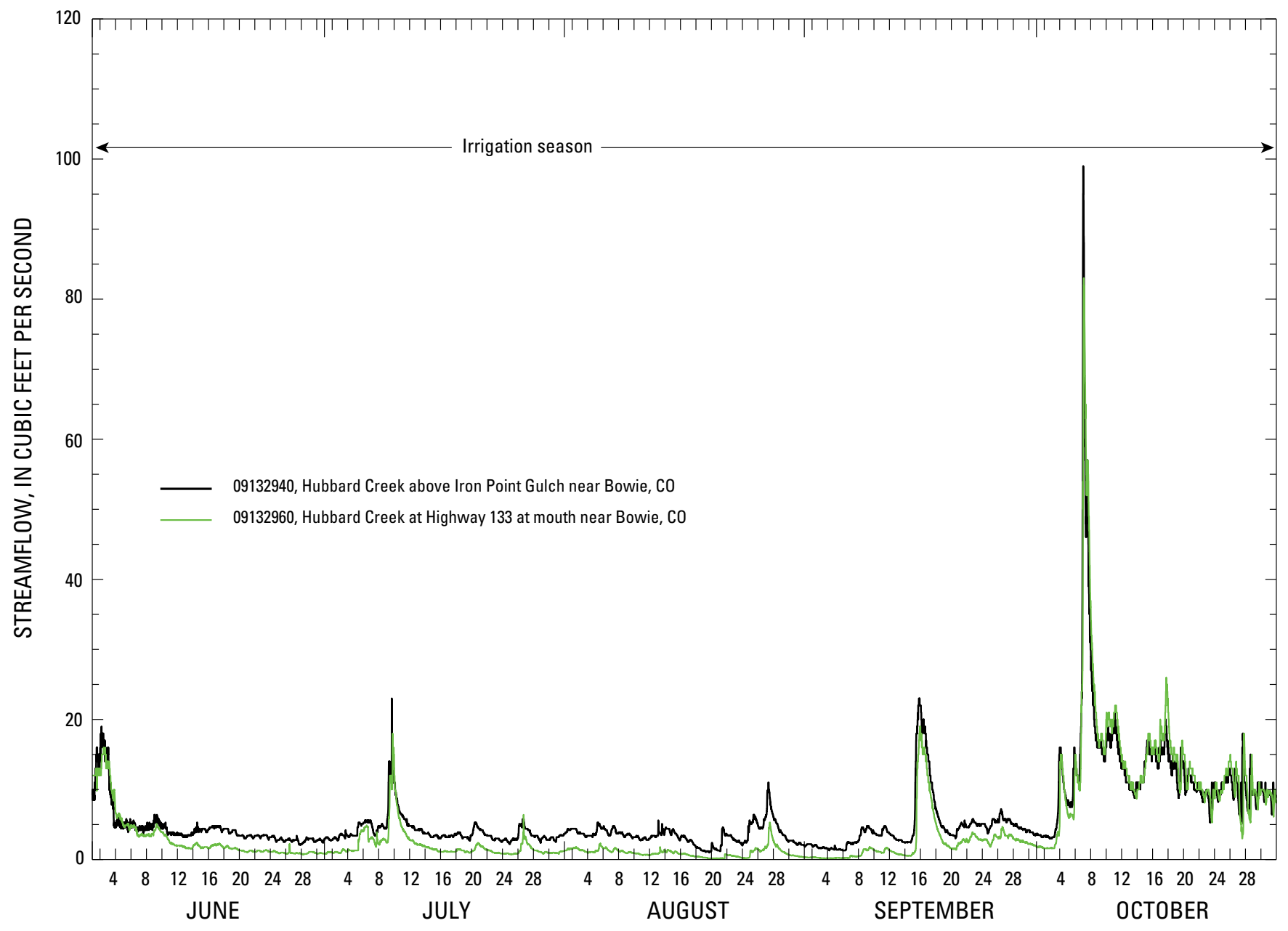

Figure 3. Streamflow data for stations 09132940, Hubbard Creek above Iron Point Gulch near Bowie, CO, and 09132960, Hubbard Creek at Highway 133 at mouth near Bowie, C0, June 1-October 31, 2006. 


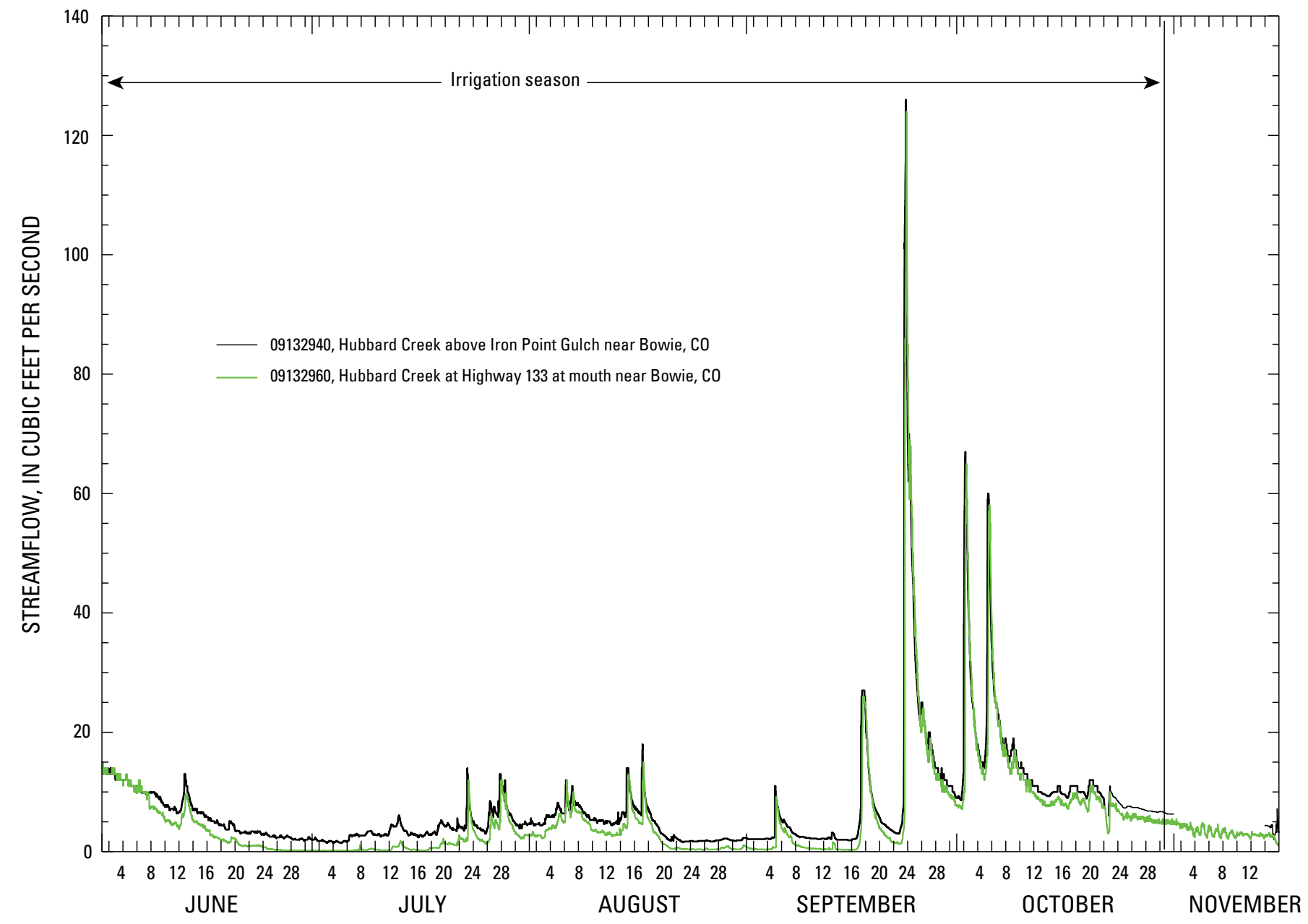

Figure 4. Streamflow data for stations 09132940, Hubbard Creek above Iron Point Gulch near Bowie, C0, and 09132960, Hubbard Creek at Highway 133 at mouth near Bowie, C0, June 1-November 15, 2007. 


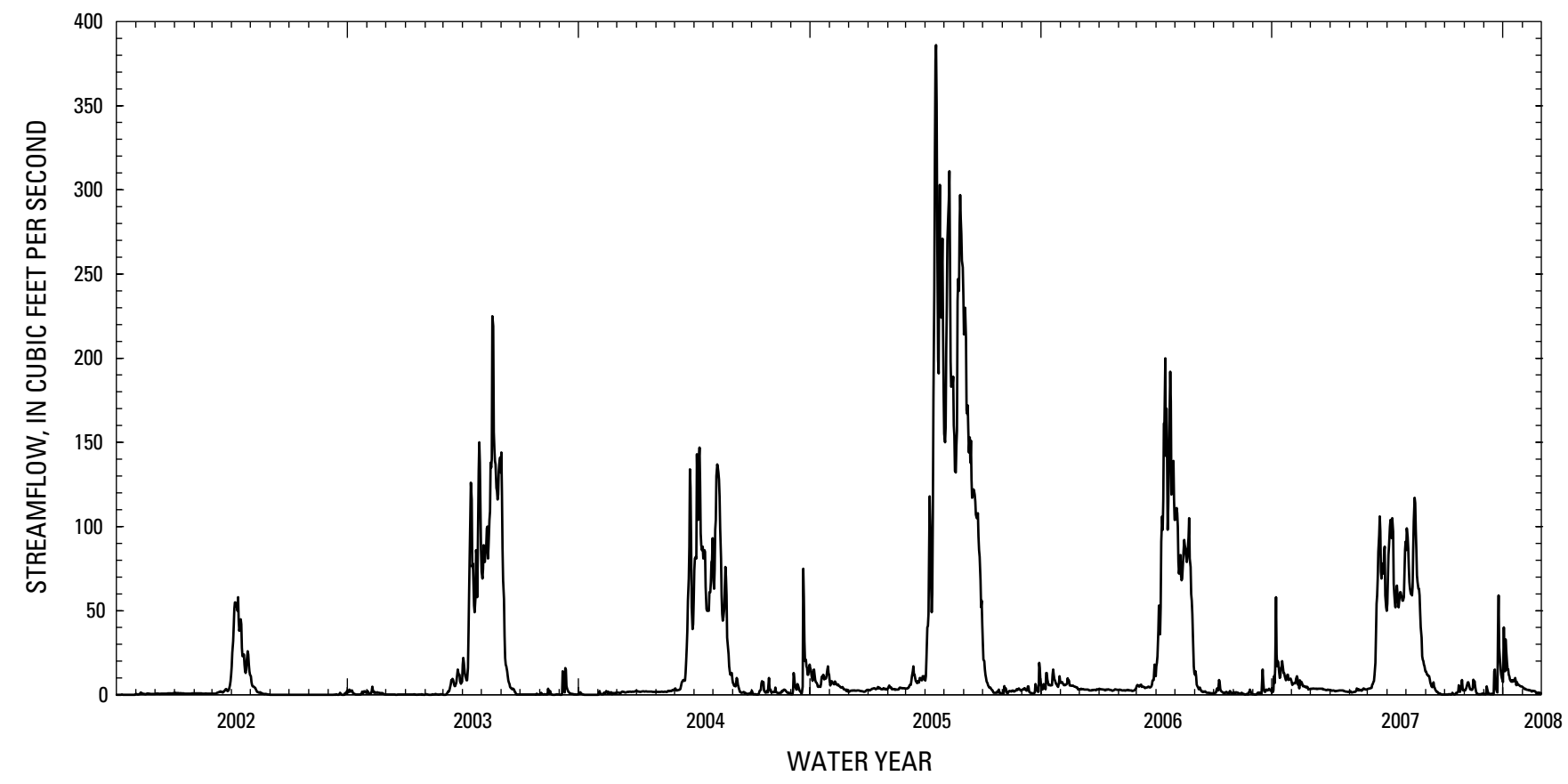

Figure 5. Streamflow data for station 09132960, Hubbard Creek at Highway 133 at mouth near Bowie, C0, 0ctober 2002 through November 2007.

Table 1. Streamflow measurement sites and streamflow-gaging stations.

\begin{tabular}{ccc}
\hline $\begin{array}{c}\text { Streamflow measurement } \\
\text { site or streamflow-gaging } \\
\text { station }\end{array}$ & $\begin{array}{c}\text { Latitude (degrees } \\
\text { minutes seconds) }\end{array}$ & $\begin{array}{c}\text { Longitude (degrees } \\
\text { minutes seconds) }\end{array}$ \\
\hline $09132940^{*}$ & $38^{\circ} 58^{\prime} 57^{\prime \prime}$ & $107^{\circ} 31^{\prime} 52^{\prime \prime}$ \\
1 & $38^{\circ} 58^{\prime} 34.445^{\prime \prime}$ & $107^{\circ} 32^{\prime} 07.059^{\prime \prime}$ \\
2 & $38^{\circ} 58^{\prime} 26.420^{\prime \prime}$ & $107^{\circ} 32^{\prime} 07.687^{\prime \prime}$ \\
3 & $38^{\circ} 58^{\prime} 06.205^{\prime \prime}$ & $107^{\circ} 32^{\prime} 05.096^{\prime \prime}$ \\
4 & $38^{\circ} 57^{\prime} 28.485^{\prime \prime}$ & $107^{\circ} 31^{\prime} 47.177^{\prime \prime}$ \\
$09132960^{*}$ & $38^{\circ} 55^{\prime} 32^{\prime \prime}$ & $107^{\circ} 31^{\prime} 04^{\prime \prime}$ \\
\hline
\end{tabular}

* Streamflow-gaging station location data are North American Datum of 1927; streamflow measurement site location data are North American Datum of 1983; 09132940, Hubbard Creek above Iron Point Gulch near Bowie, CO; 09132960, Hubbard Creek at Highway 133 at mouth near Bowie, CO. 


\section{Measurement-Site Selection}

The specific position of the four field measurement sites was determined by accessibility and the stream conditions required for injection instrumentation. It was important that the tracer setup be located in a riffle with turbulence so that the tracers would be well mixed for sampling. The location of each site was determined using a global positioning system (fig. 1). Site 1 is just downstream (0.05 mi) from Iron Point Gulch and about 0.12 mi upstream from the mine-permit area. Site 2 is at the northern boundary and upstream end of the mine-permit area. Site 3 is about 0.42 mi downstream from site 2 and within the mine-permit area. Site 4 is at the southern boundary, near the downstream end of the mine-permit area, and about $0.87 \mathrm{mi}$ downstream from site 3 . Site 4 is more than 2 mi upstream from its confluence with the North Fork Gunnison River. Sites 2 and 4 are the most meaningful because they bracket the mine-permit boundaries.

Within each measurement site, there were three parts to the study setup (fig. 6). At the upstream end, samples were collected to determine background tracer concentrations. The tracer/injection was set up at the center of the measurement site. At the downstream end, water samples were collected to determine the downstream tracer concentration.

\section{Accounting for Streamflow Variation}

Traveltimes (table 2) were estimated immediately before sampling by injecting a slug of potassium chloride $(\mathrm{KCl})$ solution just upstream from site 1 and monitoring specific conductance at sites $1,2,3$, and 4 . The traveltime between sites was the time difference from when one-half of the upstream peak measurement of specific conductance was measured to when one-half of the downstream peak measurement of specific conductance was measured. It was assumed that streamflow would be constant during each of the measurement sets. For the June sampling, traveltimes were estimated between sites 1, 2,3 , and 4 . For the November sampling, traveltimes were estimated between sites 2 and 4 because these sites were immediately upstream and downstream from the mine-permit area.

A comparison of computed streamflow was done to examine results between the two tracer types. Rhodamine WT and $\mathrm{NaBr}$ were simultaneously injected at a constant rate at site 2 on June 28, 2007. The tracers were injected, were given sufficient time and distance to mix, and then water samples were collected. $\mathrm{NaBr}$ samples were analyzed at the USGS National Water-Quality Laboratory (NWQL) in Denver, Colo., for low-ionic-strength bromide detection and at the USGS Colorado Water Science Center in Lakewood, Colo., for highionic-strength bromide detection. The two separate methods were required to measure the bromide concentrations based on the extreme differences of ionic strengths between the stream samples and injectate solutions. Both low- and high-ionicstrength ranges of bromide were determined using colorimetric procedures (Fishman and Friedman,1989). Rhodamine WT samples were analyzed by the USGS Colorado Water Science Center laboratory using fluorometric procedures (Wilson and others, 1986).

Four rhodamine WT samples and four $\mathrm{NaBr}$ samples were collected over 15 minutes. The mean streamflow for each tracer was compared; the mean for four $\mathrm{NaBr}$ estimates was $2.96 \mathrm{ft}^{3} / \mathrm{s}$ and the mean for four rhodamine WT estimates was $2.80 \mathrm{ft}^{3} / \mathrm{s}$ (fig. 7, table 3). (Note that calculated mean values and subsequent calculated correction factor are based on unrounded values.) Because the calculated streamflows

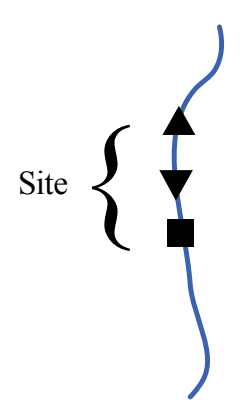

\footnotetext{
- Background site (upstream background concentration $\mathrm{C}_{\mathrm{b}}$ )

$\nabla$ Injection site (injectate concentration $\mathrm{C}_{1}$ )

Downstream site (downstream concentration $\mathrm{C}_{2}$ )
}

Figure 6. Schematic of tracer-design setup at a measurement site on Hubbard Creek. 
Table 2. Traveltime estimates collected June 25 and November 7, 2007.

\begin{tabular}{cc}
\hline Reach & Time \\
\hline site 1 to 2 & June 25, 2007 \\
site 1 to 3 & 28 minutes \\
site 1 to 4 & 1 hour 46 minutes \\
site 2 to 3 & 4 hours 55 minutes \\
site 2 to 4 & 1 hour 18 minutes \\
site 3 to 4 & 4 hours 27 minutes \\
& 3 hours 9 minutes \\
\hline site 2 to 4 & November 7, 2007 \\
\hline
\end{tabular}

should be the same regardless of tracer type, corrections were made to the streamflow data. It was determined that a correction factor (1.0579) based on the mean values of the $\mathrm{NaBr}-$ calculated streamflows and the mean values of the rhodamine WT calculated streamflow values would be used to adjust the rhodamine-WT-estimated streamflows to match the $\mathrm{NaBr}$ estimated streamflows. Previous work indicated that substantial fractions of rhodamine WT dye could be lost during a short-term multitracer injection in a mountain stream environment (Bencala and others, 1983).

During the November sampling, the tracer setup was slightly different at site 4 . There was a continuous injection and measurement of the rhodamine WT. A low-speed metering pump injected a rhodamine WT solution for about 48 hours. Downstream, where there was complete mixing, an optical measurement sonde measured the rhodamine WT concentration every 2 minutes. This setup provided continuous information for changes in streamflow and supplemented the data from the discrete samples.

\section{Streamflow Comparison Methods}

Streamflow measurements at the four measurement sites were compared to determine the gain-loss characteristics of the study reach. A graphical comparison of streamflow among measurement sites was used to evaluate gain-loss characteristics of the Hubbard Creek study reach within the same hydrologic conditions. Individual estimates of streamflow (two to six samples per measurement site) were plotted by measurement pair along with the 95 -percent confidence interval for the sample. Where the individual streamflow measurements between two paired sites did not overlap, streamflows were considered to be different. Where the individual streamflow measurements including confidence intervals between paired sites did overlap, streamflows were considered to be the same.

Statistical comparisons were done between the streamflow at the upstream and downstream sites. Two-sample t-tests (Tibco Software Inc., 2008) were performed to test for

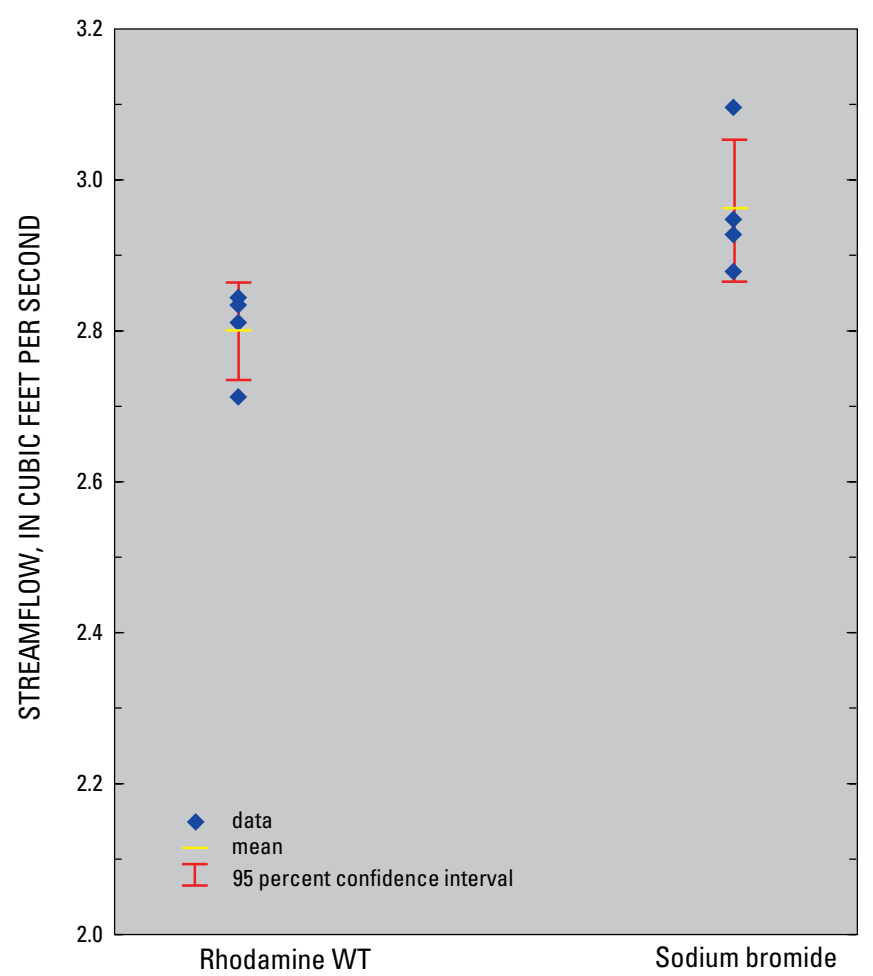

Figure 7. Estimated streamflows at site 2 for rhodamine WT andd sodium bromide tracers, June 28, 2007, at about 11:50 a.m.

differences in mean streamflow at the paired sites and also at the same site on different days. Two-sample t-tests are used to determine if the means of two populations (upstream site and downstream site) are the same or different. The data met the assumptions for parametric analysis (distributions were normal, the sample pairs were independent, and the variances were equal between data sets), which are more powerful than a nonparametric test for detecting differences. A two-sample t-test was used as opposed to a paired t-test because the individual measurements of streamflow within each site are not independent. P-values, which are the probabilities of getting a result at least as extreme as the one that was observed if the compared values were the same, were calculated.

Statistical testing (two-sample t-test) also was done between the upstream and downstream sites for all measurement pairs evaluated and between the same sites on different days. The number (n) of comparable streamflow values was small but sufficient for testing statistical significance (p-values $<0.05$ ). Measurement pairs collected at the same sites during different times of the year were not analyzed together because the streamflow conditions were different. 
Table 3. Results for tracer-comparison study, Hubbard Creek, June 28, 2007.

$\left[\mathrm{C}_{1}\right.$, tracer injection concentration; $\mathrm{C}_{2}$, downstream measured tracer concentration; $\mathrm{C}_{\mathrm{b}}$, background tracer concentration; $\mathrm{Q}_{1}$, tracer injection rate; $\mathrm{Q}_{1}$, calculated streamflow; mg/L, milligrams per liter; L/min, liters per minute; $\mathrm{ft}^{3} / \mathrm{s}$, cubic feet per second; Rh WT, rhodamine WT; NaBr, sodium bromide]

\begin{tabular}{ccccccccc}
\hline $\begin{array}{c}\text { Measurement } \\
\text { pairs }\end{array}$ & $\begin{array}{c}\text { Measurement } \\
\text { site }\end{array}$ & $\begin{array}{c}\text { Date } \\
\text { Time }\end{array}$ & $\begin{array}{c}\mathbf{C}_{\mathbf{1}} \\
(\mathbf{m g} / \mathbf{L})\end{array}$ & $\begin{array}{c}\mathbf{C}_{2} \\
(\mathbf{m g} / \mathbf{L})\end{array}$ & $\begin{array}{c}\mathbf{C}_{\mathbf{b}} \\
(\mathbf{m g} / \mathbf{L})\end{array}$ & $\begin{array}{c}\mathbf{0} \mathbf{1} \\
(\mathbf{L} / \mathbf{m i n})\end{array}$ & $\begin{array}{c}\mathbf{0} \\
(\mathbf{f t} \mathbf{3} / \mathbf{s})\end{array}$ & $\begin{array}{c}\text { Tracer } \\
\text { type }\end{array}$ \\
\hline $2-2$ & 2 & $6 / 28 / 0711: 43$ & $1,315.789$ & 0.01477 & 0.00034 & 0.053 & 2.84 & $\mathrm{Rh} \mathrm{WT}$ \\
$2-2$ & 2 & $6 / 28 / 0711: 48$ & $1,315.789$ & 0.01484 & 0.00036 & 0.053 & 2.83 & $\mathrm{Rh} \mathrm{WT}$ \\
$2-2$ & 2 & $6 / 28 / 0711: 53$ & $1,315.789$ & 0.01495 & 0.00035 & 0.053 & 2.81 & $\mathrm{Rh} \mathrm{WT}$ \\
$2-2$ & 2 & $6 / 28 / 0711: 58$ & $1,315.789$ & 0.01546 & 0.00033 & 0.053 & 2.71 & $\mathrm{Rh} \mathrm{WT}$ \\
$2-2$ & 2 & $6 / 28 / 0711: 44$ & 304,700 & 2.92000 & 0.00000 & 0.048 & 2.95 & $\mathrm{NaBr}$ \\
$2-2$ & 2 & $6 / 28 / 0711: 49$ & 304,700 & 2.78000 & 0.00000 & 0.048 & 3.10 & $\mathrm{NaBr}$ \\
$2-2$ & 2 & $6 / 28 / 0711: 54$ & 304,700 & 2.94000 & 0.00000 & 0.048 & 2.93 & $\mathrm{NaBr}$ \\
$2-2$ & 2 & $6 / 28 / 0711: 59$ & 304,700 & 2.99000 & 0.00000 & 0.048 & 2.88 & $\mathrm{NaBr}$ \\
\hline
\end{tabular}

\section{Evaluation of Streamflow and Gain- Loss Characteristics}

The data for determination of streamflow gain-loss characteristics for the study of Hubbard Creek included data collection at four measurement sites in June 2007 and two measurement sites in November 2007. Comparison of streamflow at the measurement sites (from upstream to downstream) was used to determine areas of gain or loss. Graphical and statistical comparisons were made for the three measurement sets in June and the two measurement sets in November.

\section{June 2007 Measurement Set, Streamflow Gain- Loss Characteristics}

On June 26-27, 2007, streamflow was measured at three measurement-site pairs (table 4). Sites 1 and 4 were included in measurement pair one. Sites 2 and 4 were included in measurement pair two. Sites 2 and 3 were included in measurement pair three.

All measurement pairs used rhodamine WT at the upstream site and $\mathrm{NaBr}$ at the downstream site. Traveltimes were estimated before sampling so that the same mass of water was measured at each site. Ideally, streamflow conditions would have been steady state, but there was about a $0.5-\mathrm{ft}^{3} / \mathrm{s}$ variation in streamflow between station 09132940 upstream from the mine-permit boundary and inflow from Iron Point Gulch. There was a $0.1-\mathrm{ft}^{3} / \mathrm{s}$ variation in streamflow at station 09132960, downstream from the mine-permit boundary and upstream from the confluence with the North Fork Gunnison (fig. 8). The data at both streamflow-gaging stations showed overall decreasing streamflow over time.

At measurement sites 1-4, streamflows are generally about $1 \mathrm{ft}^{3} / \mathrm{s}$ larger than at station 09132940 , indicating that
Iron Point Gulch contributed about $1 \mathrm{ft}^{3} / \mathrm{s}$ to Hubbard Creek. However, on June 26, streamflow at site 4 was similar to the streamflow at station 09132940 at about $2.7 \mathrm{ft}^{3} / \mathrm{s}$. On June 27, the streamflow at site 4 was about $3.7 \mathrm{ft}^{3} / \mathrm{s}$ and the streamflow at station 09132940 was about $2.5 \mathrm{ft}^{3} / \mathrm{s}$. The discharge at station 09131940 showed a slight increase in streamflow during midday each day even though the overall streamflow had been decreasing. It appears that a pulse of additional flow moved through the system and was measured at site 4 on June 27.

Streamflows at sites 1-4 were generally about $3 \mathrm{ft}^{3} / \mathrm{s}$ larger than at station 09132960 (fig. 8). During the irrigation season, water is diverted from Hubbard Creek downstream from the study reach and upstream from station 09132960. Also, station 09132960 is located $100 \mathrm{ft}$ upstream from the confluence with the North Fork Gunnison and downstream from where the creek enters the valley floor. Streamflow here likely contributes to the shallow groundwater in the valley floor alluvium. Therefore, data at station 09132960 have limited use to infer streamflow characteristics in the study reach except to note that diurnal variation probably occurs in the study reach and that the stream flows all the way to the mouth even during irrigation season.

On June 26, tracer-streamflow data indicated a significant loss in mean streamflow of $1.14 \mathrm{ft}^{3} / \mathrm{s}$ between sites 1 and 4 (p-value $<0.00001$ ) (table 5). There may have been a localized increase in streamflow at site 1 from Iron Point Gulch that had not reached site 4 when flow was measured there.

On June 27, data indicated a significant increase in mean streamflow of $0.33 \mathrm{ft}^{3} / \mathrm{s}$ between sites 2 and 4 (p-value $=$ $0.0011)$ but no change in streamflow between sites 2 and 3 $(p-v a l u e=1.0)($ table 5$)$. This result indicates a gain in streamflow between sites 3 and 4 . Streamflow was relatively stable at both stations during these measurements, and small changes are likely due to observed diurnal variations. The traveltimes between sites were followed closely, so the same mass of water should have been measured at each site. 
Table 4. Results for modified multiple-tracer method, Hubbard Creek, June and November 2007.

$\left[C_{1}\right.$, tracer injection concentration; $C_{2}$, downstream measured tracer concentration; $C_{b}$, background tracer concentration; $Q_{1}$, tracer injection rate; $Q$, calculated streamflow; $\mathrm{mg} / \mathrm{L}$, milligrams per liter; $\mathrm{L} / \mathrm{min}$, liters per minute; $\mathrm{ft}^{3} / \mathrm{s}$, cubic feet per second; Rh WT, rhodamine WT; $\mathrm{NaBr}$, sodium bromide]

\begin{tabular}{|c|c|c|c|c|c|c|c|c|}
\hline \multicolumn{9}{|c|}{ June 26-27, 2007} \\
\hline $\begin{array}{c}\text { Measure- } \\
\text { ment } \\
\text { pairs }\end{array}$ & $\begin{array}{c}\text { Measure- } \\
\text { ment } \\
\text { site }\end{array}$ & $\begin{array}{c}\text { Date and } \\
\text { Time }\end{array}$ & $\begin{array}{c}C_{1} \\
\text { (mg/L) }\end{array}$ & $\begin{array}{c}C_{2} \\
(m g / L)\end{array}$ & $\underset{(m g / L)}{C_{b}}$ & $\begin{array}{c}\mathbf{0}_{1} \\
(\mathrm{~L} / \mathrm{min})\end{array}$ & $\begin{array}{c}0 \\
\left(\mathrm{ft}^{3} / \mathrm{s}\right)\end{array}$ & $\begin{array}{c}\text { Tracer } \\
\text { type }\end{array}$ \\
\hline $1-4$ & 1 & $6 / 26 / 0711: 45$ & $1,254.970$ & 0.00891 & 0.00030 & 0.042 & 3.81 & Rh WT \\
\hline $1-4$ & 1 & $6 / 26 / 0712: 30$ & $1,254.970$ & 0.00891 & 0.00030 & 0.042 & 3.95 & Rh WT \\
\hline $1-4$ & 4 & $6 / 26 / 07$ 17:10 & 279,550 & 2.63000 & 0.00000 & 0.051 & 2.81 & $\mathrm{NaBr}$ \\
\hline $1-4$ & 4 & $6 / 26 / 0717: 15$ & 279,550 & 2.63000 & 0.00000 & 0.051 & 2.81 & $\mathrm{NaBr}$ \\
\hline $1-4$ & 4 & $6 / 26 / 07$ 17:20 & 279,550 & 2.71000 & 0.00000 & 0.051 & 2.73 & $\mathrm{NaBr}$ \\
\hline $1-4$ & 4 & $6 / 26 / 0717: 25$ & 279,550 & 2.70000 & 0.00000 & 0.051 & 2.74 & $\mathrm{NaBr}$ \\
\hline $1-4$ & 4 & $6 / 26 / 07$ 17:30 & 279,550 & 2.79000 & 0.00000 & 0.051 & 2.65 & $\mathrm{NaBr}$ \\
\hline $1-4$ & 4 & $6 / 26 / 0717: 36$ & 279,550 & 2.75000 & 0.00000 & 0.051 & 2.69 & $\mathrm{NaBr}$ \\
\hline $2-4$ & 2 & $6 / 27 / 0713: 24$ & $1,267.475$ & 0.01264 & 0.00050 & 0.052 & 3.38 & Rh WT \\
\hline $2-4$ & 2 & $6 / 27 / 0713: 29$ & $1,267.475$ & 0.01264 & 0.00042 & 0.052 & 3.36 & Rh WT \\
\hline $2-4$ & 2 & $6 / 27 / 0713: 34$ & $1,267.475$ & 0.01261 & 0.00045 & 0.052 & 3.37 & Rh WT \\
\hline $2-4$ & 2 & $6 / 27 / 07$ 13:39 & $1,267.475$ & 0.01397 & 0.00043 & 0.052 & 3.25 & Rh WT \\
\hline $2-4$ & 4 & $6 / 27 / 07$ 17:52 & 278,150 & 2.05000 & 0.02000 & 0.040 & 3.63 & $\mathrm{NaBr}$ \\
\hline $2-4$ & 4 & $6 / 27 / 07$ 17:56 & 278,150 & 2.08000 & 0.02000 & 0.040 & 3.58 & $\mathrm{NaBr}$ \\
\hline $2-4$ & 4 & $6 / 27 / 07$ 18:02 & 278,150 & 2.03000 & 0.02000 & 0.040 & 3.66 & $\mathrm{NaBr}$ \\
\hline $2-4$ & 4 & 6/27/07 18:07 & 278,150 & 1.96000 & 0.02000 & 0.040 & 3.80 & $\mathrm{NaBr}$ \\
\hline $2-3$ & 2 & $6 / 27 / 0720: 20$ & 1267.475 & 0.01324 & 0.00039 & 0.054 & 3.32 & Rh WT \\
\hline $2-3$ & 2 & $6 / 27 / 0720: 25$ & 1267.475 & 0.01339 & 0.00034 & 0.054 & 3.27 & Rh WT \\
\hline $2-3$ & 2 & $6 / 27 / 0720: 30$ & 1267.475 & 0.01324 & 0.00048 & 0.054 & 3.34 & Rh WT \\
\hline $2-3$ & 2 & $6 / 27 / 0720: 35$ & 1267.475 & 0.01318 & 0.00038 & 0.054 & 3.33 & Rh WT \\
\hline $2-3$ & 3 & $6 / 27 / 0721: 38$ & 276,550 & 2.44000 & 0.02000 & 0.050 & 3.36 & $\mathrm{NaBr}$ \\
\hline $2-3$ & 3 & $6 / 27 / 0721: 43$ & 276,550 & 2.52000 & 0.02000 & 0.050 & 3.26 & $\mathrm{NaBr}$ \\
\hline $2-3$ & 3 & $6 / 27 / 0721: 46$ & 276,550 & 2.41000 & 0.02000 & 0.050 & 3.40 & $\mathrm{NaBr}$ \\
\hline $2-3$ & 3 & $6 / 27 / 0721: 54$ & 276,550 & 2.53000 & 0.02000 & 0.050 & 3.24 & $\mathrm{NaBr}$ \\
\hline
\end{tabular}


Table 4. Results for modified multiple-tracer method, Hubbard Creek, June and November 2007._Continued

$\left[\mathrm{C}_{1}\right.$, tracer injection concentration; $\mathrm{C}_{2}$, downstream measured tracer concentration; $\mathrm{C}_{\mathrm{b}}$, background tracer concentration; $\mathrm{Q}_{1}$, tracer injection rate; $\mathrm{Q}$, calculated streamflow; mg/L, milligrams per liter; L/min, liters per minute; $\mathrm{ft}^{3} / \mathrm{s}$, cubic feet per second; Rh WT, rhodamine WT; NaBr, sodium bromide]

\begin{tabular}{|c|c|c|c|c|c|c|c|c|}
\hline \multicolumn{9}{|c|}{ November 8-9, 2007} \\
\hline $\begin{array}{c}\text { Measure- } \\
\text { ment } \\
\text { pairs }\end{array}$ & $\begin{array}{c}\text { Measure- } \\
\text { ment } \\
\text { site }\end{array}$ & $\begin{array}{l}\text { Date and } \\
\text { Time }\end{array}$ & $\begin{array}{c}C_{1} \\
(m g / L)\end{array}$ & $\begin{array}{c}C_{2} \\
(\mathrm{mg} / \mathrm{L})\end{array}$ & $\underset{(\mathrm{mg} / \mathrm{L})}{\mathrm{C}_{\mathrm{b}}}$ & $\begin{array}{c}\mathbf{0}_{1} \\
(\mathrm{~L} / \mathrm{min})\end{array}$ & $\begin{array}{c}0 \\
\left(\mathrm{ft}^{3} / \mathrm{s}\right)\end{array}$ & $\begin{array}{c}\text { Tracer } \\
\text { type }\end{array}$ \\
\hline $2-4$ & 2 & 11/8/07 11:18 & 261,800 & 3.81000 & 0.01000 & 0.082 & 3.32 & $\mathrm{NaBr}$ \\
\hline $2-4$ & 2 & $11 / 8 / 0711: 20$ & 261,800 & 3.73000 & 0.01000 & 0.082 & 3.40 & $\mathrm{NaBr}$ \\
\hline $2-4$ & 2 & $11 / 8 / 0711: 22$ & 261,800 & 3.77000 & 0.01000 & 0.082 & 3.36 & $\mathrm{NaBr}$ \\
\hline $2-4$ & 2 & 11/8/07 11:23 & 261,800 & 3.77000 & 0.01000 & 0.082 & 3.36 & $\mathrm{NaBr}$ \\
\hline $2-4$ & 2 & $11 / 8 / 0711: 24$ & 261,800 & 3.82000 & 0.01000 & 0.082 & 3.32 & $\mathrm{NaBr}$ \\
\hline $2-4$ & 4 & $11 / 8 / 0714: 20$ & $1,566.961$ & 0.01359 & 0.00023 & 0.052 & 3.76 & Rh WT \\
\hline $2-4$ & 4 & $11 / 8 / 0714: 22$ & $1,566.961$ & 0.01306 & 0.00023 & 0.052 & 3.92 & $\mathrm{Rh}$ WT \\
\hline $2-4$ & 4 & $11 / 8 / 0714: 24$ & $1,566.961$ & 0.01338 & 0.00023 & 0.052 & 3.82 & $\mathrm{Rh}$ WT \\
\hline $2-4$ & 4 & $11 / 8 / 0714: 26$ & $1,566.961$ & 0.01237 & 0.00023 & 0.052 & 4.14 & Rh WT \\
\hline $2-4$ & 4 & $11 / 8 / 0714: 26$ & $1,566.961$ & 0.01242 & 0.00023 & 0.052 & 4.12 & Rh WT \\
\hline $2-4$ & 2 & 11/9/07 10:18 & 267,700 & 2.49000 & 0.01000 & 0.057 & 3.62 & $\mathrm{NaBr}$ \\
\hline $2-4$ & 2 & 11/9/07 10:19 & 267,700 & 2.43000 & 0.01000 & 0.057 & 3.71 & $\mathrm{NaBr}$ \\
\hline $2-4$ & 2 & 11/9/07 10:20 & 267,700 & 2.45000 & 0.01000 & 0.057 & 3.68 & $\mathrm{NaBr}$ \\
\hline $2-4$ & 2 & $11 / 9 / 0710: 22$ & 267,700 & 2.55000 & 0.01000 & 0.057 & 3.54 & $\mathrm{NaBr}$ \\
\hline $2-4$ & 2 & $11 / 9 / 0710: 24$ & 267,700 & 2.53000 & 0.01000 & 0.057 & 3.56 & $\mathrm{NaBr}$ \\
\hline $2-4$ & 4 & 11/9/07 13:20 & $1,566.961$ & 0.01272 & 0.00020 & 0.040 & 3.27 & Rh WT \\
\hline $2-4$ & 4 & $11 / 9 / 0713: 22$ & $1,566.961$ & 0.01271 & 0.00020 & 0.040 & 3.28 & Rh WT \\
\hline $2-4$ & 4 & $11 / 9 / 07$ 13:22 & $1,566.961$ & 0.01258 & 0.00020 & 0.040 & 3.31 & Rh WT \\
\hline $2-4$ & 4 & $11 / 9 / 0713: 24$ & $1,566.961$ & 0.01284 & 0.00020 & 0.040 & 3.24 & Rh WT \\
\hline $2-4$ & 4 & $11 / 9 / 0713: 26$ & $1,566.961$ & 0.01278 & 0.00020 & 0.040 & 3.26 & Rh WT \\
\hline
\end{tabular}




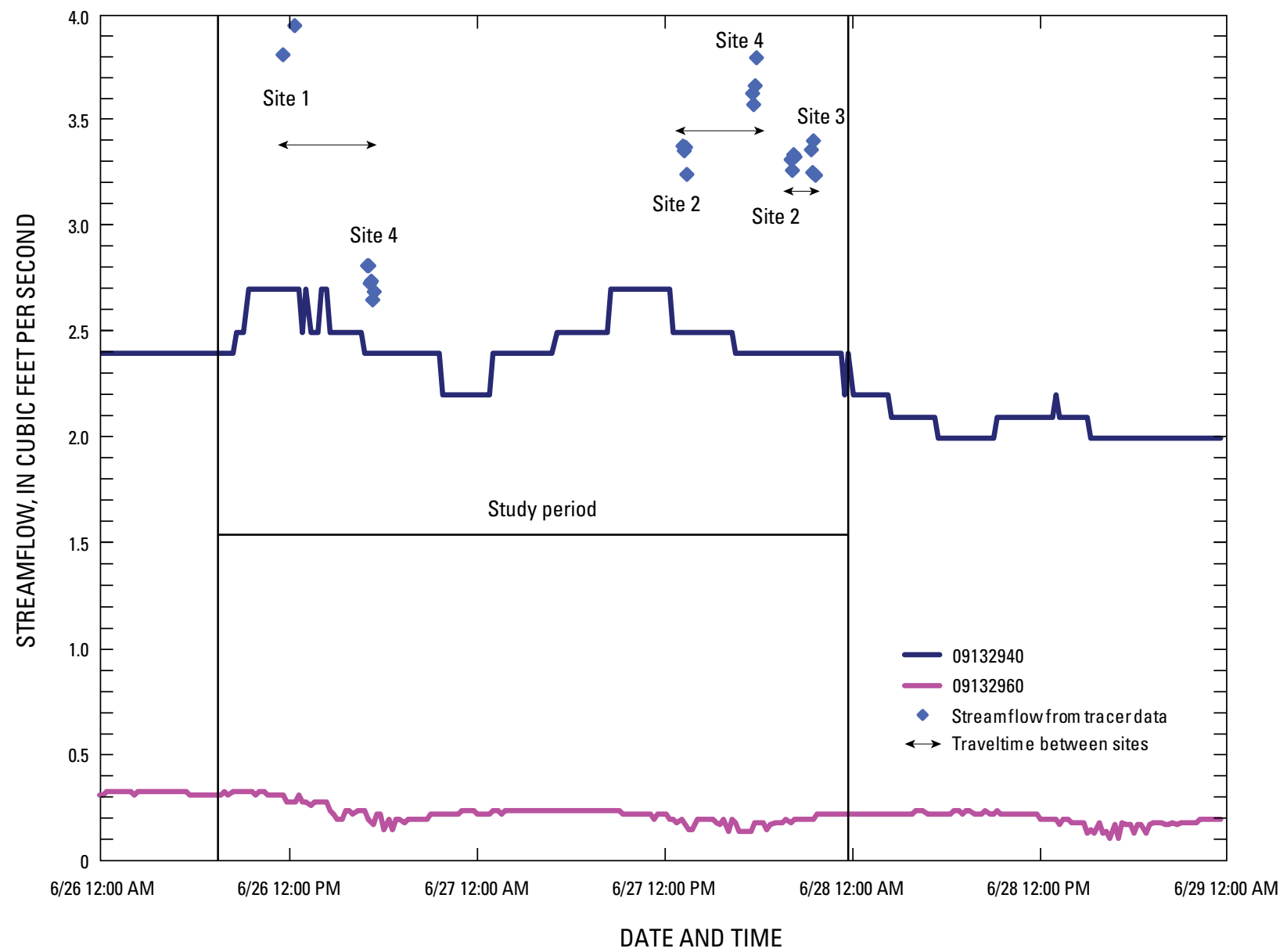

Figure 8. Streamflow data for stations 09132940, Hubbard Creek above Iron Point Gulch near Bowie, CO, and 09132960, Hubbard Creek at Highway 133 at mouth near Bowie, C0, and streamflow estimated from discrete tracer samples, June 26-27, 2007. 
Table 5. Various statistics for the measurement pairs by site, June and November, 2007.

$\left[\mathrm{ft}^{3} / \mathrm{s}\right.$, cubic feet per second; $<$, less than]

\begin{tabular}{|c|c|c|c|c|c|c|c|}
\hline $\begin{array}{l}\text { Measure- } \\
\text { ment pairs }\end{array}$ & $\begin{array}{l}\text { Measure- } \\
\text { ment site }\end{array}$ & $\begin{array}{l}\text { Date and } \\
\text { time }\end{array}$ & $\begin{array}{l}\text { Mean streamflow } \\
\left(\mathrm{ft}^{3} / \mathbf{s}\right)\end{array}$ & $\begin{array}{l}\text { Standard } \\
\text { deviation }\end{array}$ & t-value & p-value & $\begin{array}{c}\text { Degrees of } \\
\text { freedom }\end{array}$ \\
\hline $1-4$ & 1 & 6/26/07 12:08 & 3.88 & 0.098995 & 19.6815 & $<0.00001$ & 6 \\
\hline $1-4$ & 4 & 6/26/07 17:23 & 2.74 & 0.064005 & & & \\
\hline $2-4$ & 2 & 6/27/07 13:32 & 3.34 & 0.060553 & -5.8449 & 0.0011 & 6 \\
\hline $2-4$ & 4 & 6/27/07 17:59 & 3.67 & 0.094296 & & & \\
\hline $4-4$ & 4 & $6 / 26 / 07 \quad 17: 23$ & 2.74 & 0.064005 & -18.7484 & $<0.00001$ & 8 \\
\hline $4-4$ & 4 & 6/27/07 17:59 & 3.67 & 0.094296 & & & \\
\hline $2-3$ & 2 & 6/27/07 20:28 & 3.32 & 0.031091 & 0.0000 & 1.0000 & 6 \\
\hline $2-3$ & 3 & 6/27/07 21:45 & 3.32 & 0.077244 & & & \\
\hline $2-2$ & 2 & 6/27/07 13:32 & 3.34 & 0.060553 & 0.7346 & 0.4903 & 6 \\
\hline $2-2$ & 2 & 6/27/07 20:28 & 3.32 & 0.031091 & & & \\
\hline $2-4$ & 2 & 11/8/07 11:21 & 3.35 & 0.033466 & -7.6397 & 0.0001 & 8 \\
\hline $2-4$ & 4 & $11 / 8 / 0714: 24$ & 3.95 & 0.172395 & & & \\
\hline $2-4$ & 2 & 11/9/07 10:21 & 3.62 & 0.073621 & 10.0287 & $<0.00001$ & 8 \\
\hline $2-4$ & 4 & 11/9/07 13:23 & 3.27 & 0.025884 & & & \\
\hline $2-2$ & 2 & 11/8/07 11:21 & 3.35 & 0.033466 & -7.4655 & 0.0001 & 8 \\
\hline $2-2$ & 2 & 11/9/07 10:21 & 3.62 & 0.073621 & & & \\
\hline $4-4$ & 4 & 11/8/07 14:24 & 3.95 & 0.172395 & 8.7223 & $<0.00001$ & 8 \\
\hline $4-4$ & 4 & 11/9/07 13:23 & 3.27 & 0.025884 & & & \\
\hline
\end{tabular}

The inconsistency between the calculated mean streamflows for the paired measurement sites and the variability in the diurnal streamflow at the two streamflow-gaging stations indicates a dynamic stream reach. Sampling occurred during a hot, dry period, but overall June precipitation was 125 percent of the 1971-2001 June average (Colorado Climate Center, 2008). This may have affected the antecedent conditions and the interaction of streamflow and shallow groundwater. The data show a large decrease in streamflow between sites 1 and 4 on June 26 (fig. 8). This may be due to recharge to shallow groundwater between sites 1 and 4 . There is a statistically significant increase (p-value $<0.00001)$ in streamflow at site 4 on the second day (June 27) even though the sampling occurred at approximately the same time during the 24-hour period. On June 26, the mean streamflow at site 4 was $2.74 \mathrm{ft}^{3} / \mathrm{s}$ and on June 27 the mean streamflow was $3.67 \mathrm{ft}^{3} / \mathrm{s}$, an increase of $0.93 \mathrm{ft}^{3} / \mathrm{s}$ (fig. 9 and table 5). The observed differences in streamflow may be due to pulses of streamflow moving through the reach and being measured at some sites and not at others. A small amount of difference also may be due to measurement error. On June 27, there is a statistically significant increase ( $p$-value $=0.0011)$ in streamflow between sites 2 and 4 and no statistically significant difference $(\mathrm{p}$-value $=1.0000)$ in streamflow between sites 2 and 3 or at site 2 (p-value $=$ 0.4903 ) at different times during the same day.

\section{November 2007 Measurement Set, Streamflow Gain-Loss Characteristics}

The second set of measurements occurred November 8-9, 2007 and included two comparisons of streamflow between sites 2 and 4 . The measurement pairs used $\mathrm{NaBr}$ at the upstream site (site 2) and rhodamine WT at the downstream site (site 4). Five sets of paired data were collected but only two were used in the analysis of streamflow gain-loss due to variations in traveltime resulting from inconsistent streamflow (table 4). Sampling was delayed until November because precipitation was greater than average in September and October, affecting low-flow conditions. In November, low-flow conditions existed; but unfortunately, the colder temperatures resulted in other factors affecting streamflow, such as freezing 


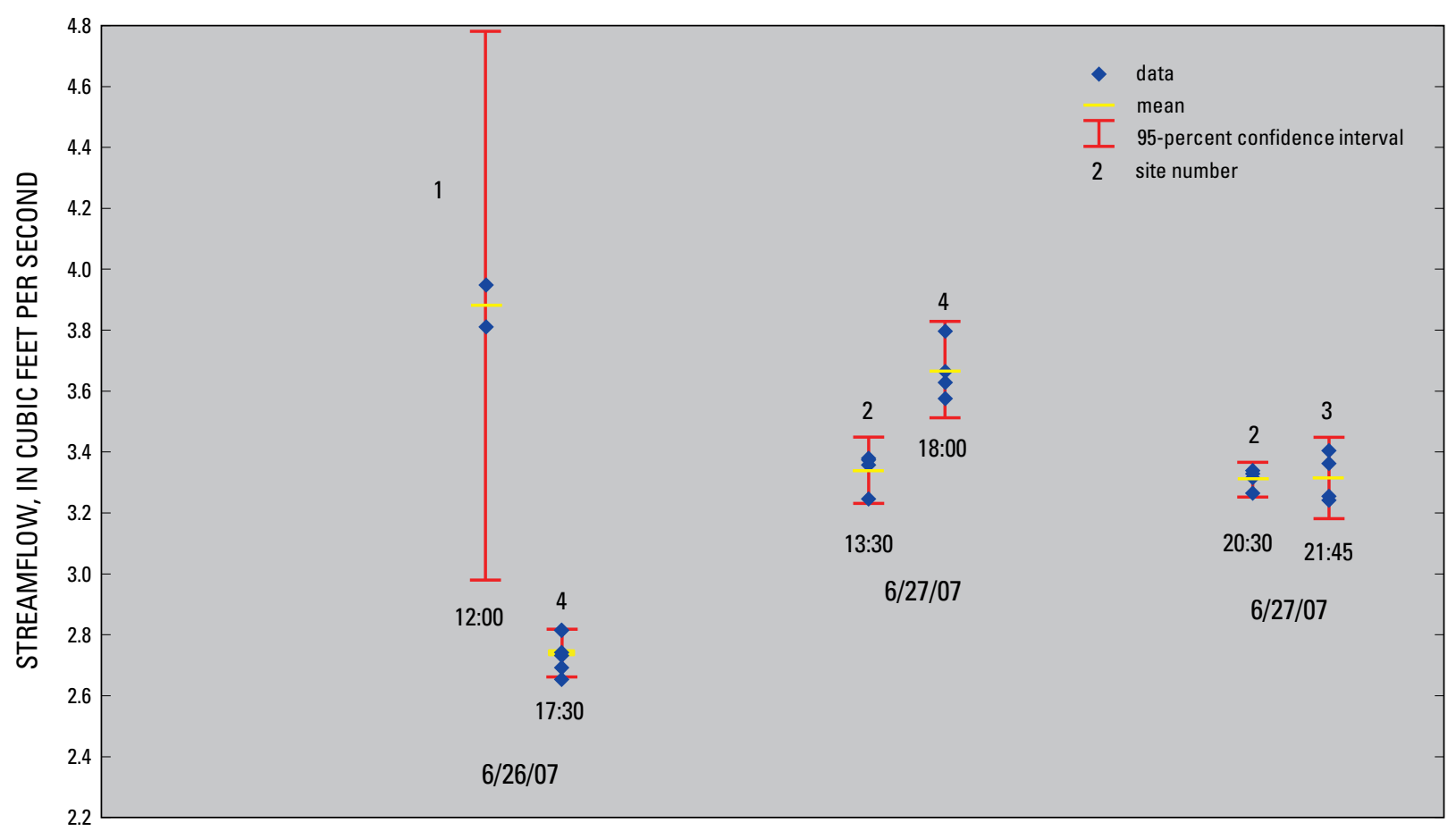

DATE AND AVERAGE TIME FOR EACH MEASUREMENT SET

Figure 9. Estimated streamflows at sites 2-4, June 26-27, 2007.

and melting of stream ice. Streamflow-gaging record at station 09132960, downstream from the study reach and mine-permit area, shows the variation in streamflow of as much as $1.5 \mathrm{ft}^{3} / \mathrm{s}$ during the study period (fig. 10).

As described in the "Methods" section, during this sampling period at site 4 , concentrations of rhodamine WT were continuously monitored. There was variability in the optical measurement sonde data; therefore, outliers were removed and a 10-point moving average was plotted to visualize the general streamflow pattern (fig. 10). During sampling, field personnel noted a rise in stream stage of at least $0.5 \mathrm{ft}$, which supports the changing rhodamine WT concentrations recorded by the sonde. The graph shows that streamflow at site 4 ranged from about $2.75 \mathrm{ft}^{3} / \mathrm{s}$ to about $6 \mathrm{ft}^{3} / \mathrm{s}$, indicating that streamflow conditions were not steady state. The streamflow at station 09132960 ranged between 2.1 and $3.6 \mathrm{ft}^{3} / \mathrm{s}$ during the study period and showed a similar muted pattern with a time-delay offset.

For the statistical comparison for each of the two measurement pairs, the five estimates of streamflow collected at the upstream site (site 2) were averaged and compared to the average of the five estimates of streamflow collected at the downstream site (site 4) (fig. 11 and table 4). On November 8, 2007, the data indicated a significant increase in mean streamflow from $3.35 \mathrm{ft}^{3} / \mathrm{s}$ at site 2 to $3.95 \mathrm{ft}^{3} / \mathrm{s}$ at site 4 (p-value of 0.0001$)$. The increase in streamflow of $0.6 \mathrm{ft}^{3} / \mathrm{s}$ measured between sites 2 and 4 follows the rising hydrograph recorded by the sonde. This increase in streamflow is likely due to melting stream ice in different parts of the basin contributing to streamflow as exposure to the sun changes and is not indicative that this is a consistently gaining reach.

On November 9, again, there was a decrease in mean

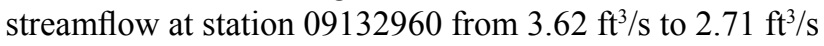
during the study reach measurement period. On this day, a decrease in mean streamflow of $0.35 \mathrm{ft}^{3} / \mathrm{s}$ was measured between sites 2 and 4. Sampling on November 9 occurred one hour earlier, prior to the rising hydrograph caused by stream ice melt, when the conditions were more steady state than the previous day. This may indicate that this is a losing reach.

\section{Comparison of June and November 2007 Measurement Sets}

Based on streamflow from the upper, seasonal station (09132940) and the lower station (09132960) and from the tracer tests at sites 1 through 4 , one can conclude that streamflow on this reach of Hubbard Creek is dynamic and can vary substantially between sites. The data showed diurnal and day-to-day variations in streamflow and that the streamflow is perennial. Furthermore, the reach between sites 2 and 4, which are at the upstream and downstream end of the mine-permit area, can be gaining, losing, or constant, depending on local 


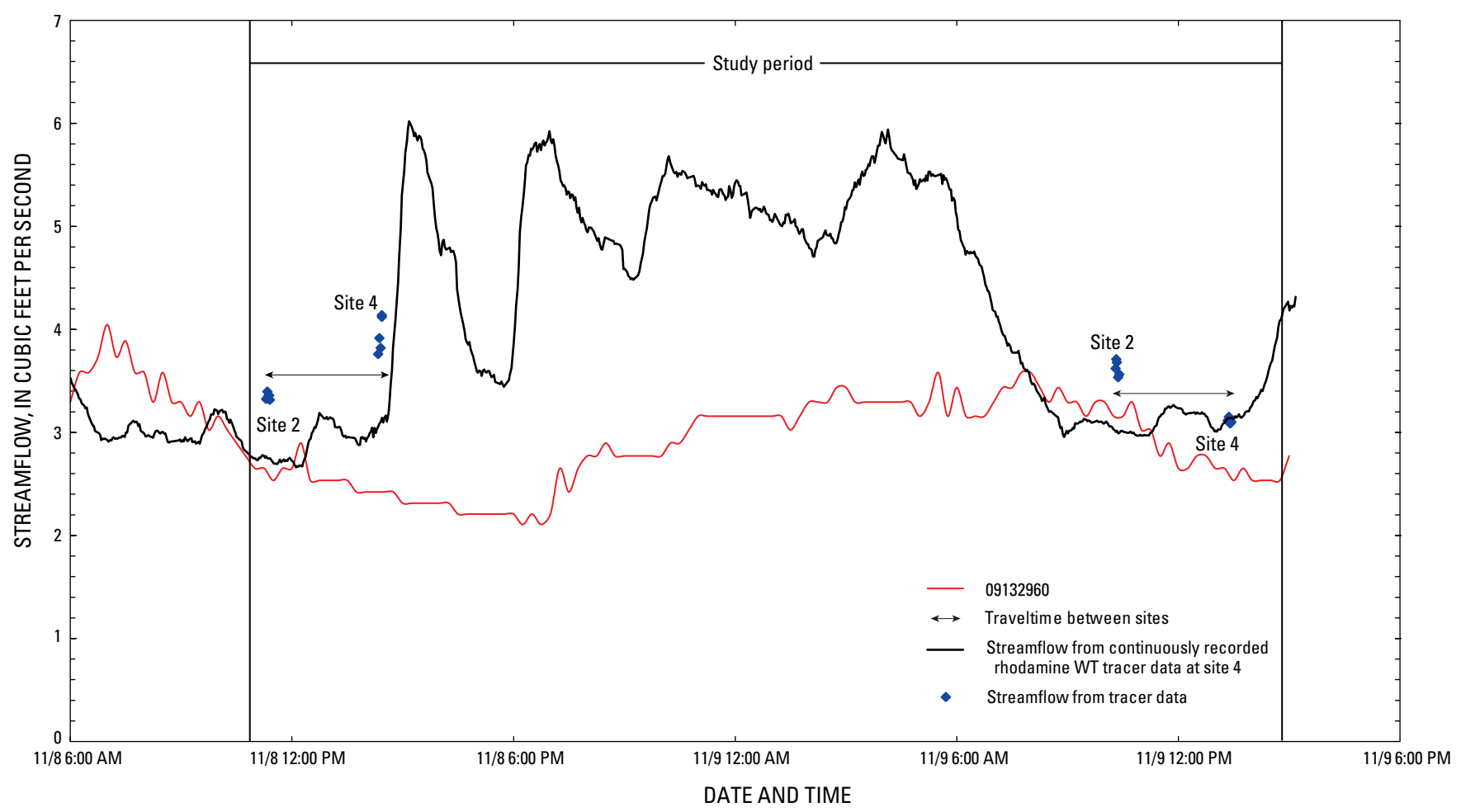

Figure 10. Streamflow data for station 09132960, Hubbard Creek at Highway 133 at mouth near Bowie, C0, and streamflow estimated from discrete and continuously recorded tracer samples, November 8-9, 2007.

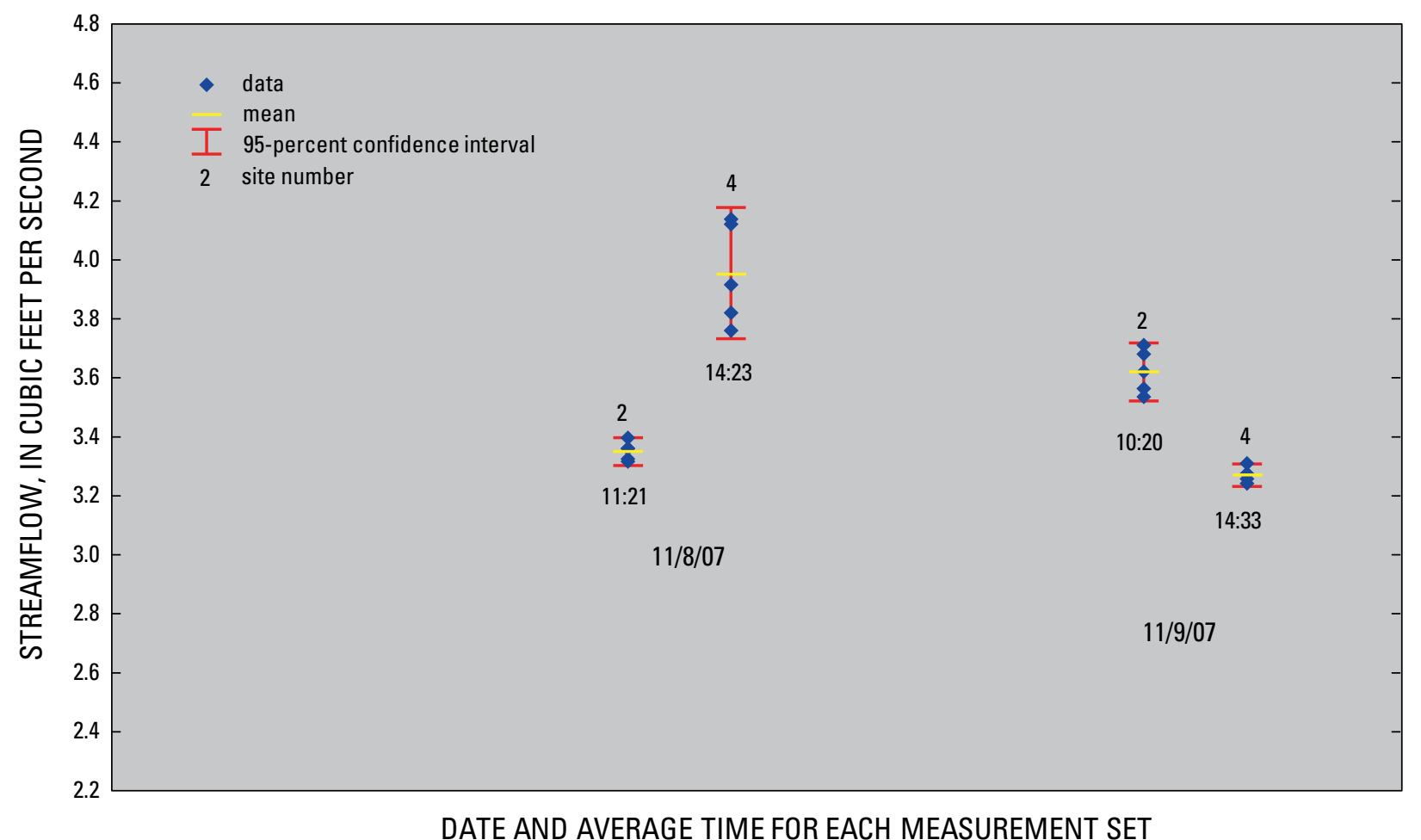

Figure 11. Estimated streamflows at sites 2 and 4, November 8-9, 2007. 
inputs. Conditions during both measurement sets were not ideal. During June, streamflow varied within each measurement site over the multiple sampling days. During November, freezing and melting of stream ice affected streamflow.

Over the irrigation season, streamflow is greater in the study reach than at the upper station, partly due to inflow from Iron Point Gulch and other tributaries. Because of irrigation diversions from Hubbard Creek downstream from the study reach, streamflow at the lower station is usually less than at the upper station and the study reach.

Diurnal variations in streamflow are common at both the upper and the lower stations. The upper station shows a melt-freeze influence from tributaries to Hubbard Creek with maximum streamflow occurring around midday (fig. 8). Downstream from the study reach, observed diurnal variation is likely due to evapotranspiration associated with dense floodplain vegetation, which consumes water from the creek during the middle of the day. Varying diurnal patterns in streamflow, combined with possible variations in tributary inflows to Hubbard Creek in the study reach, probably account for most of the observed variations in streamflow at the tracer measurement sites.

During November (part of the nonirrigation season), streamflow at the lower station was five to six times greater than that during the irrigation season (fig. 4). Also, streamflows at the study reach generally exceeded streamflows at the lower station, indicating that some loss occurred between these locations. Streamflow at the lower station and at sites 2 and 4 in the study reach was dominated by diurnal variations likely associated with the melting and later freezing of stream ice throughout different parts of the basin as they were exposed to sunlight. During a period of relative minimal diurnal changes on November 9 , tracer data show the reach between sites 2 and 4 was losing about $0.3 \mathrm{ft}^{3} / \mathrm{s}$.

The variability in streamflow at sites 1 through 4 in the study reach make it difficult to determine whether the streamflow is gaining or losing within the study reach. However, data from the stations and tracer tests provide general reference points that could be used in the future to help determine if subsequent mining activities could affect streamflow in Hubbard Creek.

\section{Summary}

In 2007, the U.S. Geological Survey, in cooperation with Bowie Mining Company, initiated a study to characterize the streamflow gain-loss characteristics in a reach of Hubbard Creek in Delta County, Colorado, in the vicinity of the Bowie mine permit area prior to mining. Premining streamflow characteristics and gain-loss variation were determined so that premining and postmining gain-loss characteristics could be compared. The methods used in this study and results of two measurement sets collected in June and November 2007 are presented in this report.

In June 2007 and November 2007, data were collected at four streamflow-measurement sites on Hubbard Creek, which flows along the northeast side of the mine-permit area. Two different tracers, rhodamine WT and $\mathrm{NaBr}$, were used in this study, and a comparison of flow estimates between the tracers was done. The estimated streamflow using the rhodamine WT tracer was slightly less than the estimated streamflow using the $\mathrm{NaBr}$ tracer. Because the calculated streamflows should be the same, a correction factor of 1.0579 was applied to the rhodamine WT streamflow data.

The first set of measurements was collected at the four sites spanning the mine-permit area on June 26-28, 2007. Streamflows were estimated and compared between sites 1 and 4, sites 2 and 4, and sites 2 and 3. On June 26, streamflow was greater at site 1 than at site 4; on June 27, streamflow was greater at site 4 than at site 2; and on June 27, there was no difference in streamflow between sites 2 and 3 . The data from the stations 09132940 and 09132960 show diurnal variations and overall decreasing streamflow over time. The data indicate a dynamic system, and streamflow can increase or decrease depending on hydrologic conditions. Generally, the streamflow within the study reach was greater than the streamflows at either the upstream or downstream stations.

A second set of measurements was collected at sites 2 and 4 on November 8-9, 2007. On November 8, streamflow was greater at site 4 than at site 2; on the following day, November 9 , streamflow was greater at site 2 than at site 4 . Data collection on November 8 occurred while the streamflow was increasing due to contributions from stream ice melting throughout different parts of the basin. Data collection on November 9 occurred during less variable conditions and indicated that streamflow decreased slightly between sites 2 and 4 , which was consistent with streamflow at the downstream station.

During the sampling periods in June and November 2007, conditions were less than ideal and not steady state. The June 27 sampling indicated that the streamflow was increasing between measurement sites 2 and 4, and the November 9 sampling indicated that the streamflow was decreasing between measurement sites 2 and 4 . The data showed diurnal and dayto-day variations in streamflow, the streamflow is perennial, and the study reach can be gaining, losing, or constant. These variations occurred during low-flow conditions at different times of the year.

\section{Acknowledgments}

The authors gratefully acknowledge the following USGS colleagues for their contributions to the report and project success: Dave Mueller and Brent Troutman for their assistance in the data statistical analysis; Rob Runkel and Katie Walton-Day 
for their guidance in tracer study analysis and data statistical analysis; Andrea Fleming and Alisa Mast for the sample analyses; Anne Hayden for data analyses; and Anne Hayden, Craig Muelot, Ken Leib, and Jude Thomas for their assistance in the field. Technical reviews of the report were made by Ken Leib and David Mau.

\section{References Cited}

Bencala, K.E., Rathbun, R.E., Jackman, A.P., Kennedy, V.C., Zellweger, G.W., and Avanzino, R.J., 1983, Rhodamine WT dye losses in a mountain stream environment: Water Resources Bulletin, v. 19, no. 6, p. 943-950.

Bowie Resources, Limited, 2008, Coal companies-General overview: http://www.uprr.com/customers/energy/coal/ company/bowie.shtml, accessed July 18, 2008).

Brooks, Tom, 1983, Hydrology and subsidence potential of proposed coal-lease tracts in Delta County, Colorado: U.S. Geological Survey Water-Resources Investigations 83-4069, 27 p.

Chaney, T.H., Kuhn, Gerhard, Brooks, Tom, and others, 1987 , Hydrology of Area 58, Northern Great Plains and Rocky Mountain coal provinces, Colorado and Utah: U.S. Geological Survey Water-Resources Investigations/Open-File Report 85-479, 103 p.

Colorado Climate Center, Colorado State University, 2008, accessed September 17, 2008, http://ccc.atmos.colostate. edu/ odie/wateryr08.prn.

DiLuzio, Mario, 2007, Seamless daily precipitation for the conterminous United States, 1960-2001: Data available from the U.S. Department of Agriculture Geospatial Data Gateway, accessed June 11, 2008, http://datagateway.nrcs. usda.gov/NextPage.aspx.

Dunrud, R.C., 1976, Some engineering geologic factors controlling coal mine subsidence in Utah and Colorado: U.S. Geological Survey Professional Paper 969, 39 p.

Ellis, M.S., Gaskill, D.L., and Dunrud, R.C., 1987, Geologic map of the Paonia and Gunnison area, Delta and Gunnison Counties, Colorado: U.S. Geological Survey Coal Investigations Map C-109.

Energy Information Administration, 2008, Coal production report-Major U.S. coal mines, 2007: Data available from Energy Information Administration, 2008, accessed October 7, 2008, http://www.eia.doe.gov/cneaf/coal/page/acr/table9. $x l s$.
Fishman, M.J., and Friedman, L.C., 1989, Methods for determination of inorganic substances in water and fluvial sediments: U.S. Geological Survey Techniques of WaterResources Investigations, book 5, chap A1, Method ID I-2129-89, 545 p.

Green. G.N., 1992, The digital geologic map of Colorado in ARC/INFO format: U.S. Geological Survey Open-File Report 92-0507.

Kilpatrick, F.A., and Cobb, E.D., 1985, Measurement of discharge using tracers: U.S. Geological Survey-Techniques of Water Resources Investigations book 3, chap. A16, 52 p.

Marchand, J.P., Jarrett, R.D., and Jones, L.L., 1984, Velocity profile, water-surface slope, and bed-material size for selected streams in Colorado: U.S. Geological Survey Open-File Report 84-733, 82 p.

Oxbow Corporation, 2008, http://www.oxbow.com/ ContentPageSSL.asp $? F N=$ ServicesMining $\& T S=2 \& M S=14$, accessed July 18, 2008.

Rantz, S.E., and others, 1982, Measurement and computation of streamflow, volume 1. Measurement of stage and discharge: U.S. Geological Survey Water-Supply Paper 2175, v. 1,284 p.

Theobald, D.M., Wilcox, G., Linn, S.E., Peterson, N., and Lineal, M., 2008, Colorado ownership, management, and protection v7 database: Human Dimensions of Natural Resources and Natural Resource Ecology Laboratory, Fort Collins, Colorado State University, https://www.nrel.colostate.edu/projects/comap/.

Tibco Software Inc., 2008, Spotfire S+ 8.1 for Windows, twosample t-test: Palo Alto, Calif., Tibco Software Inc.

U.S. Geological Survey, 2008, National Water Information System (NWISWeb) data available on the World Wide Web, accessed multiple times in 2008 and 2009, http://waterdata. usgs.gov/co/nwis/sw.

Williams, C.A., and Leib, K.J., 2005, Using tracers to evaluate streamflow gain-loss characteristics of Terror Creek, in the vicinity of a mine-permit area, Delta County, Colorado, water year 2003: U.S. Geological Survey Scientific Investigations Report 2005-5018.

Wilson, J.F., Jr., Cobb, E.D., and Kilpatrick, F.A., 1986, Fluometric procedures for dye tracing: U.S. Geological SurveyTechniques of Water Resources Investigations book 3, chap. A12, 34 p.

Zellweger, G.W., 1994, Testing and comparison of four ionic tracers to measure stream flow loss by multiple tracer injection: Hydrological Processes, v. 8, p. 155-165. 
Publishing support provided by:

Denver Publishing Service Center

For more information concerning this publication, contact:

Director, USGS Colorado Water Science Center

Box 25046, Mail Stop 415

Denver, CO 80225

(303) 236-4882

Or visit the Colorado Water Science Center Web site at: http://co.water.usgs.gov/ 
$\stackrel{ }{ }$

좋

흘

$\frac{9}{\Phi}$ 